\title{
Global Monitoring of the Vegetation Dynamics from the Vegetation Optical Depth (VOD): A Review
}

\author{
Frédéric Frappart ${ }^{1,2}, * \mathbb{0}$, Jean-Pierre Wigneron ${ }^{2}$, Xiaojun $\mathrm{Li}^{2}$, Xiangzhuo Liu ${ }^{2}{ }^{\oplus}$, \\ Amen Al-Yaari ${ }^{3}{ }^{-}$, Lei Fan ${ }^{4}{ }^{(0)}$, Mengjia Wang ${ }^{2,5}$, Christophe Moisy ${ }^{2}$, Erwan Le Masson ${ }^{2}$, \\ Zacharie Aoulad Lafkih ${ }^{2}$, Clément Vallé ${ }^{2}$, Bertrand Ygorra ${ }^{2,6}$ and Nicolas Baghdadi ${ }^{7}$ (D) \\ 1 LEGOS, Université de Toulouse, CNES, CNRS, IRD, UPS-14 avenue Edouard Belin, 31400 Toulouse, France \\ 2 INRAE, UMR1391 ISPA, Université de Bordeaux, F-33140 Villenave d'Ornon, France; \\ jean-pierre.wigneron@inrae.fr (J.-P.W.); xiaojun.li@inrae.fr (X.L.); xiangzhuo.liu@inrae.fr (X.L.); \\ mengjia.wang@inrae.fr (M.W.); christophe.moisy@inrae.fr (C.M.); erwan.lemasson@inrae.fr (E.L.M.); \\ zacharie.aoulad@inrae.fr (Z.A.L.); clement.valle@inrae.fr (C.V.); bertrand.ygorra@visioterra.fr (B.Y.) \\ 3 Sorbonne Université, UMR 7619 METIS, Case 105, 4 place Jussieu, F-75005 Paris, France; \\ amen.al-yaari@upmc.fr \\ 4 School of Geographical Sciences, Nanjing University of Information Science and Technology, Nanjing 210044, \\ China; lei.fan@nuist.edu.cn \\ 5 State Key Laboratory of Remote Sensing Science, Faculty of Geographical Science, Beijing Normal University, \\ Beijing 100875, China \\ 6 VisioTerra, 14 rue Albert Einstein, 77420 Champs-sur-Marne, France \\ 7 INRAE, UMR TETIS, University of Montpellier, 500 rue François Breton, CEDEX 5, 34093 Montpellier, \\ France; nicolas.baghdadi@teledetection.fr \\ * Correspondence: frederic.frappart@legos.obs-mip.fr
}

Received: 15 July 2020; Accepted: 6 September 2020; Published: 8 September 2020

\begin{abstract}
Vegetation is a key element in the energy, water and carbon balances over the land surfaces and is strongly impacted by climate change and anthropogenic effects. Remotely sensed observations are commonly used for the monitoring of vegetation dynamics and its temporal changes from regional to global scales. Among the different indices derived from Earth observation satellites to study the vegetation, the vegetation optical depth (VOD), which is related to the intensity of extinction effects within the vegetation canopy layer in the microwave domain and which can be derived from both passive and active microwave observations, is increasingly used for monitoring a wide range of ecological vegetation variables. Based on different frequency bands used to derive VOD, from L- to Ka-bands, these variables include, among others, the vegetation water content/status and the above ground biomass. In this review, the theoretical bases of VOD estimates for both the passive and active microwave domains are presented and the global long-term VOD products computed from various groups in the world are described. Then, major findings obtained using VOD are reviewed and the perspectives offered by methodological improvements and by new sensors onboard satellite missions recently launched or to be launched in a close future are presented.
\end{abstract}

Keywords: vegetation optical depth (VOD); brightness temperature $\left(\mathrm{T}_{\mathrm{B}}\right)$; backscattering; radiative transfer; vegetation; above ground biomass (AGB); vegetation water content (VWC)

\section{Introduction}

Vegetation distribution, phenology and productivity are very sensitive to climate change which impacts all terrestrial ecosystems [1-6]. Latitudinal and altitudinal vegetation shifts due to increase in temperature were observed in many ecosystems around the world increasing their vulnerability [2,7-10]. Vegetation experienced earlier onset and an increase in the length of the greening period in the northern 
hemisphere due to warmer temperatures [11-13]. These changes have a strong impact on vegetation productivity especially over semi-arid areas and northern latitudes with large decrease and increase, respectively [4-6]. The increase in occurrence and severity in climate extreme, both wet and dry, is responsible for abrupt changes in phenology and vegetation productivity [4,9]. Extreme droughts increase the mortality of vegetation and the occurrence of fires $[9,14,15]$. Ten to fifty percent of the land surfaces are very likely to be highly vulnerable. The biomes with highest vulnerability are the temperate mixed forest, the boreal conifer, tundra, and alpine biomes mostly because of potential changes in wildfire whereas tropical evergreen broadleaf forests and desert biomes exhibit a lower vulnerability [8]. Phenology also exerts a strong control on many feedbacks of the vegetation to the climate system through the albedo seasonality, the conductance of the canopy, the surface roughness length, and the water, energy, $\mathrm{CO}_{2}$ fluxes and biogenic volatile organic compounds (see [1] for a review). These effects on the vegetation are likely to be exacerbated in the future decades according to different climate scenarios [8,16-18].

Satellite remote sensing is a powerful tool to monitor the vegetation dynamics and its temporal changes from the local to the global scales owing to the great diversity of Earth observation satellites (EOS) providing complementary active and passive observations in a wide range of the frequency domains, and at various spatial and temporal resolutions. Multi-spectral images have been used to derive a wide number of spectral vegetation indices based on reflectance ratios as the most commonly used normalized difference vegetation index (NDVI), defined as the ratio of the difference between the near infrared (NIR) and red reflectance and their sum [19] or the enhanced vegetation index (EVI) computed as the ratio of linear combinations of the NIR, red and blue reflectance [20]. These indices are indicators of the vegetation photosynthetic activity [21-24] and productivity [25-27]. They were also identified as proxies of leaf area index (LAI) [28-30], fractional vegetation cover [28,31,32] or fraction of photosynthetically active radiation (fPAR) [33-37]. In the microwave field, for wavelengths ranging from $1 \mathrm{~mm}$ to $1 \mathrm{~m}$, or from 0.3 to $300 \mathrm{GHz}$ in terms of frequency, remotely sensed observations are acquired by either passive (radiometer) or active (radar) sensors. Radiometers measure brightness temperatures ( $\mathrm{T}_{\mathrm{B}}$ expressed in $\mathrm{K}$ ) corresponding to the natural radiation emitted by the land surface (Figure 1a). These sensors have a coarse spatial resolution that increases with frequency (from several tenths of kilometers at L-band $(\sim 1.4 \mathrm{GHz})$ to a few kilometers at Ka-band ( 36 GHz) [38]. Radar sensors measure the ratio between backscattered and the transmitted microwave radiations (Figure 1b). Spaceborne radar sensors are of two types: real aperture radar (scatterometers and altimeters) with a coarse spatial resolution from a few to tenths of kilometers and synthetic aperture radar (SAR) with a higher spatial resolution from a few meters to a few hundreds of meters. As for the radiometers, the spatial resolution increases with the frequency. For SAR, it also depends on the acquisition mode [39,40]. Observations at frequencies below $\sim 14 \mathrm{GHz}$ are less sensitive to atmospheric effects and more sensitive to the water present in the vegetation [41], and the lower frequencies (i.e., the longer wavelengths), the better their capabilities to penetrate deeper within the canopy and the soil, and as a consequence are more sensitive to soil moisture [42] (Figure 2).

The vegetation cover strongly affects the brightness temperatures measured by radiometers as the vegetation canopy absorbs and scatters the soil emission and adds its own emission to the total radiative flux $[43,44]$. Likewise, the vegetation canopy widely impacts the radar backscattering observation which is determined by the dielectric constant of the vegetation that depends on its moisture content, the distribution of the size, shape, and orientation of the scatters, the geometry of the canopy cover (i.e., direction, spacing, cover fraction, etc.) [45]. Both the passive and active observations were early used to estimate the vegetation water content (VWC) [46-50] and the biomass [44,51-56]. The vegetation optical depth (VOD) parameterizes the extinction effects due to the vegetation affecting the microwave radiations propagating through the vegetation canopy. As passive and active microwave observations are available since the end of the 1970s $([57,58]$ and Table 1$)$, long-term time-series of VOD are available at different frequency bands, e.g., L (1-2 GHz), C (4-8 GHz)., X (8-12 GHz), K (18-26.5 GHz), and can 
be used to monitor the temporal variations in the vegetation features (e.g., VWC, biomass) in response to both the climate and anthropogenic effects [59,60].
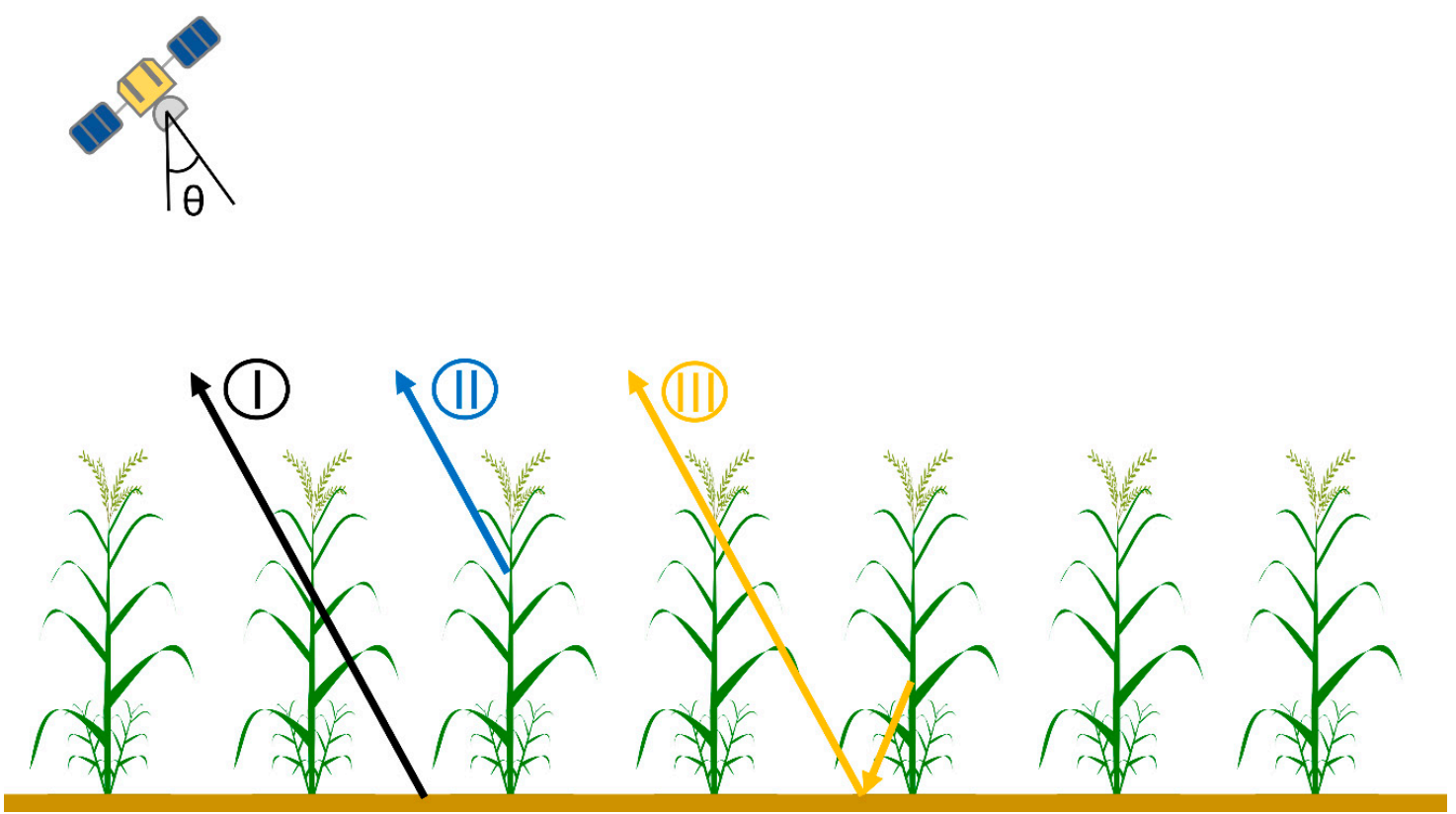

(a)
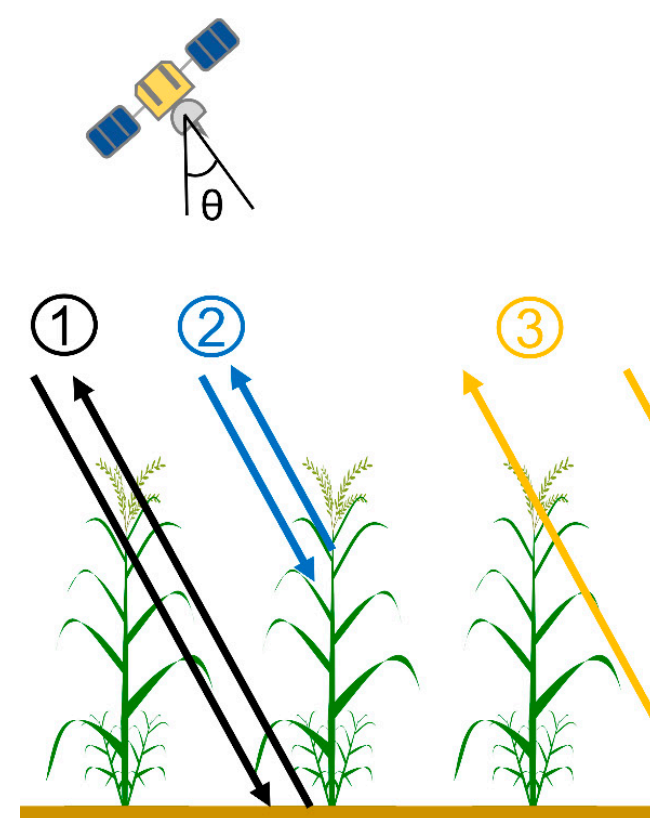

(4)
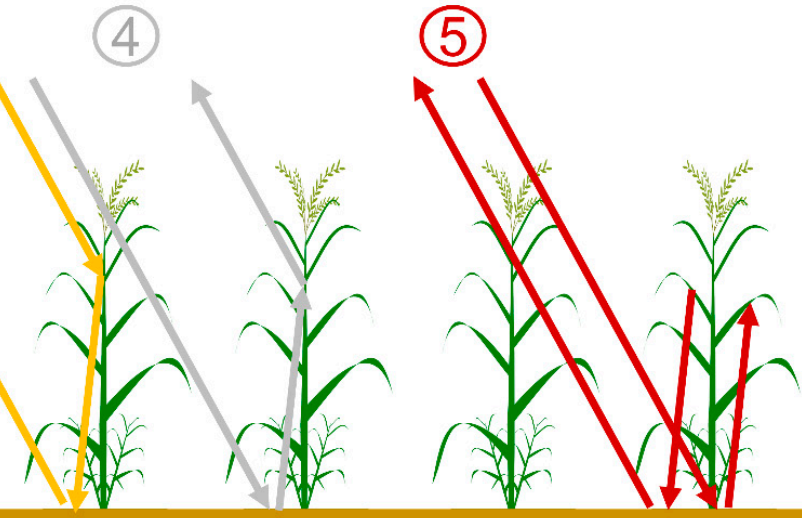

(b)

Figure 1. Mechanisms for microwave land surface emission (a) and backscattering (b). (a) Direct emission by soil including one-way attenuation by canopy (I-black), direct upward emission by plants (II—blue), vegetation emission downward followed by reflection (III—orange); (b) Single-scattering contributions in a vegetation canopy: direct backscattering from soil including two-way attenuation by canopy (1-black), direct backscattering from vegetation (2-blue), vegetation/ground scattering (3-orange), ground/vegetation scattering (4-grey), ground/vegetation/ground scattering (5—red). Adapted from [42]. 
Table 1. Main characteristics of the radiometers (Rad) and scatterometers (Scat) onboard satellite platforms which were used or could be used for vegetation optical depth (VOD) retrievals.

\begin{tabular}{|c|c|c|c|c|c|c|c|}
\hline Satellite & Sensor & Type & Frequency Band and Value (GHz) & Polarization & Spatial Resolution (km) & Swath $(\mathbf{k m})$ & In Operation \\
\hline $\begin{array}{l}\text { SEASAT, } \\
\text { Nimbus-7 }\end{array}$ & SSMR & Rad & C (6.63), X (10.69), K (18.6, 21.0), Ka (37.0) & $\mathrm{H}, \mathrm{V}$ & $27,46,91$ and 148 & $2^{1} \times 390$ & $\begin{array}{l}07 / 1978-10 / 1978 \\
10 / 1978-02 / 1995\end{array}$ \\
\hline DMSP & $\mathrm{SSM} / \mathrm{I}$ & $\mathrm{Rad}$ & K (19.35, 22.235), Ka (37.0), W (85.5) & $\mathrm{H}, \mathrm{V}^{2}$ & $12.5^{3}$ and 25 & 1400 & Since 06/1987 \\
\hline TRMM & TMI & $\mathrm{Rad}$ & $\mathrm{X}(10.7), \mathrm{K}(19.4,21.3), \mathrm{Ka}(37.0), \mathrm{W}(85.5)$ & $\mathrm{H}, \mathrm{V}$ & 5 to 45 & 780 & $12 / 1997-06 / 2015$ \\
\hline ADEOS-2 & AMSR & $\mathrm{Rad}$ & $\mathrm{K}(19.35,22.235), \mathrm{Ka}(37.0), \mathrm{W}(85.5)$ & $\mathrm{H}, \mathrm{V}$ & 5.4 to 56 & 1600 & $12 / 2002-10 / 2003$ \\
\hline Aqua & AMSR-E & $\operatorname{Rad}$ & C (6.925), X (10.65), K (18.7, 23.8), Ka (36.5), W (89.0) & $\mathrm{H}, \mathrm{V}$ & 5.4 to 56 & 1445 & 05/2002-12/2011 \\
\hline Coriolis & WindSat & $\mathrm{Rad}$ & $\mathrm{C}(6.8), \mathrm{X}(10.7), \mathrm{K}(18.7,23.8), \mathrm{Ka}(37)$ & $\mathrm{H}, \mathrm{V}$ & 8 to 40 & 1000 & Since $01 / 2003$ \\
\hline SMOS & MIRAS & $\mathrm{Rad}$ & $\mathrm{L}(1.41)$ & $\mathrm{H}, \mathrm{V}$ & 40 & 1000 & Since 11/2009 \\
\hline SAC-D/Aquarius & ALRad & $\mathrm{Rad}$ & $\mathrm{L}(1.413)$ & $\mathrm{H}, \mathrm{V}$ & 36 & 390 & 06/2011-06/2015 \\
\hline GCOM-W1 & AMSR2 & Rad & C $(6.925,7.3)$, X (10.65), K (18.7, 23.8), Ka (36.5), W (89.0) & $\mathrm{H}, \mathrm{V}$ & 5.4 to 56 & 1445 & Since $05 / 2012$ \\
\hline GPM & GMI & Rad & $\mathrm{X}(10.65), \mathrm{K}(18.7,23.8), \mathrm{Ka}(37.0), \mathrm{W}(89), \mathrm{mm}(165.5,183.31)$ & $\mathrm{H}, \mathrm{V}^{4}$ & 4.4 to 19.4 & 885 & Since 03/2014 \\
\hline SEASAT & SASS & Scat & $\mathrm{Ku}(14.599)$ & $\mathrm{HH}, \mathrm{VV}$ & $\sim 50$ & $2 \times 500$ & 07/1978-10/1978 \\
\hline ERS-1 & WS & Scat & $C(5.3)$ & VV & 50 & 500 & 07/1991-03/2000 \\
\hline ERS-2 & WS & Scat & C (5.3) & VV & 50 & 500 & 04/1995-09/2011 \\
\hline ADEOS-1 & NSCAT & Scat & $\mathrm{Ku}(13.995)$ & $\mathrm{HH}, \mathrm{VV}$ & 25 and 50 & $2 \times 600$ & 08/1996-06/1997 \\
\hline QuikSCAT & SeaWinds & Scat & $\mathrm{Ku}(13.4)$ & $\mathrm{HH}, \mathrm{VV}$ & $\sim 25$ & 1800 & 06/1999-11/2009 \\
\hline ADEOS-2 & SeaWinds & Scat & $\mathrm{Ku}(13.4)$ & $\mathrm{HH}, \mathrm{VV}$ & $\sim 25$ & 1800 & $12 / 2002-10 / 2003$ \\
\hline METOP-A & ASCAT & Scat & C (5.255) & VV & 25 and 50 & $2 \times 550$ & Since 10/2006 \\
\hline SAC-D/Aquarius & ALScat & Scat & $\mathrm{L}(1.26)$ & $\mathrm{HH}, \mathrm{VV}, \mathrm{VH}, \mathrm{HV}$ & 36 & 390 & $06 / 2011-06 / 2015$ \\
\hline METOP-B & ASCAT & Scat & $C(5.255)$ & VV & 25 and 50 & $2 \times 550$ & Since $09 / 2012$ \\
\hline METOP-C & ASCAT & Scat & C (5.255) & VV & 25 and 50 & $2 \times 550$ & Since 11/2018 \\
\hline OCEANSat-2 & OSCAT & Scat & $\mathrm{Ku}(13.515)$ & $\mathrm{HH}, \mathrm{VV}$ & 12 to 50 & 1440,1840 & 09/2009-04/2014 \\
\hline CFOSAT & SCAT & Scat & $\mathrm{Ku}(13.256)$ & $\mathrm{HH}, \mathrm{VV}$ & 50 & 1000 & Since $10 / 2018$ \\
\hline CFOSAT & SWIM & Scat & $\mathrm{Ku}(13.525)$ & None & $\sim 7^{5}$ & 180 & Since 10/2018 \\
\hline
\end{tabular}




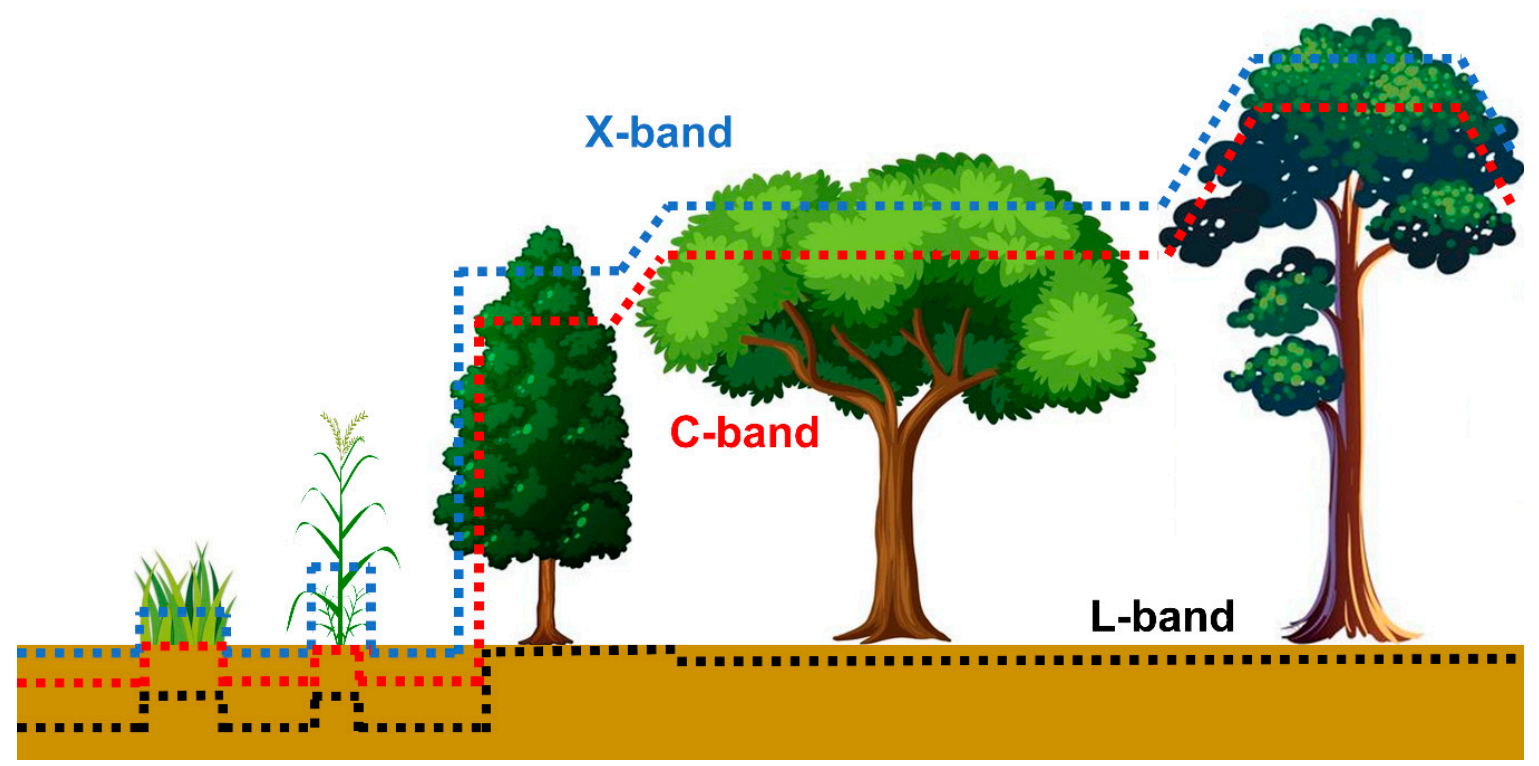

Figure 2. Penetration of the electromagnetic wave in the soil and the vegetation (grass, crop, trees) as a function of the frequency band ( $\mathrm{X}$ in blue, $\mathrm{C}$ in red, and $\mathrm{L}$ in black).

In this review, theoretical aspects of VOD retrievals from both passive and active remotely sensed microwave observations are summarized. Then, global long-term VOD products are described in terms of sensors and frequency bands used for the retrievals, period of availability and specificities of the inversion approach. Main studies based on VOD are then summarized and their results discussed to highlight the interest and potentialities of this parameter to better understand the vegetation temporal dynamics.

\section{VOD Retrievals from Passive and Active Microwave Observations}

VOD can be retrieved from both passive and active microwave data. Radiometers measure the thermal radiation emitted by the Earth's surface at a given frequency. It is given in terms of brightness temperature $\left(T_{B}\right)$ representing the temperature of an equivalent blackbody emitting the same radiation [61]. At a given microwave wavelength $(\lambda)$ /frequency $(\mathrm{f})$, and for a given temperature (T) typical of the Earth's surface, the specific intensity of blackbody radiation $\left(\mathrm{I}_{0}\right)$ is given by the Plank's law. Considering the Rayleigh-Jeans approximation $\left(\mathrm{hf}<<\mathrm{k}_{\mathrm{B}} \mathrm{T}\right)$, it is given by:

$$
\mathrm{I}_{0}=\frac{\mathrm{k}_{\mathrm{B}} \mathrm{T}}{\lambda^{2}}
$$

where $\mathrm{h}$ is the Planck constant equals to $6.62607015 \times 10^{-34} \mathrm{~J} \mathrm{~s}$ and $\mathrm{k}_{\mathrm{B}}$ is the Boltzmann constant equals to $1.3806488 \times 10^{-23} \mathrm{~J} \mathrm{~K}^{-1}$.

Brightness temperature is defined as the general (non-blackbody) thermal radiation of intensity $\mathrm{I}_{0}$ as follows:

$$
\mathrm{T}_{\mathrm{B}}=\frac{\lambda^{2}}{\mathrm{k}_{\mathrm{B}}} \mathrm{I}_{0}
$$

The brightness temperature $\left(T_{B}\right)$ of a thermally radiating body is linearly related to its true temperature $(\mathrm{T})$ through its emissivity (e):

$$
\mathrm{T}_{\mathrm{B}}=\mathrm{eT}
$$

Radars measure the power of the electromagnetic wave (EM) backscattered by the Earth's surface $\left(P_{r}\right)$. The reflecting properties of the surface are expressed through the backscattering coefficient $\left(\sigma^{0}\right)$ 
which is function of the emitted and reflected powers $\left(\mathrm{P}_{\mathrm{e}}\right.$ and $\mathrm{P}_{\mathrm{r}}$ respectively), the characteristics of the antenna and of the illuminated area. It is defined using the radar equation [62]:

$$
\sigma^{0}=\frac{(4 \pi)^{3} R^{4}}{\lambda^{2}} \frac{L_{e} L_{r}}{G_{e} G_{r}} \frac{P_{r}}{P_{e} S_{e f f}}
$$

where $R$ is distance between the sensor and the Earth surface, $G_{e}, G_{r}, L_{e}, L_{r}$ are the gains and losses of the antenna at the emission and reception respectively and $S_{\text {eff }}$ is the effective land surface.

\subsection{VOD from Passive Microwave Observations}

Emission of land surfaces (i.e., a rough soil covered with vegetation) in the microwave electromagnetic (EM) field can be simulated using a radiative transfer (RT) model [63]. The brightness temperature measured by the sensor onboard a satellite platform is the linear combination of effective temperatures $\mathrm{T}_{\text {soil }}$ and $\mathrm{T}_{\mathrm{veg}}$ of soil and vegetation, and the downwelling cold sky $\mathrm{T}_{\text {sky }}$ weighted by EM dependent emissivities $e_{\text {soil }}, e_{v e g}, e_{s k y}$, known as the Kirchhoff coefficients and function of the polarization $(\mathrm{p})$ and the incidence angle $(\theta)$ :

$$
\mathrm{T}_{\mathrm{B}}(\mathrm{p}, \theta)=\mathrm{e}_{\text {soil }}(\mathrm{p}, \theta) \mathrm{T}_{\text {soil }}+\mathrm{e}_{\mathrm{veg}}(\mathrm{p}, \theta) \mathrm{T}_{\mathrm{veg}}+\mathrm{e}_{\text {sky }}(\mathrm{p}, \theta) \mathrm{T}_{\text {sky }}
$$

with:

$$
\mathrm{e}_{\text {soil }}(\mathrm{p}, \theta)+\mathrm{e}_{\mathrm{veg}}(\mathrm{p}, \theta)+\mathrm{e}_{\mathrm{sky}}(\mathrm{p}, \theta)=1
$$

for the conservation of the energy.

The contribution of the atmosphere is generally neglected at rather low frequencies $(f<\sim 15 \mathrm{GHz}$ ). RT models of variable complexity were developed to represent the contributions of soil and vegetation to the measured $\mathrm{T}_{\mathrm{B}}$. The most commonly used is the simplified (zero-order, i.e., the scattering phase function is set to zero) Tau-Omega ( $\tau-\omega)$ model [63]. In this model, the soil and the vegetation radiative components are represented by a single homogeneous layer and the scattering phase function is set to zero. For the $\tau-\omega$ model, the emissivities are defined as:

$$
\left\{\begin{array}{c}
\mathrm{e}_{\text {soil }}(\mathrm{p}, \theta)=\left(1-\mathrm{s}_{\text {soil }}(\mathrm{p}, \theta)\right) \mathrm{t}(\theta) \\
\mathrm{e}_{\mathrm{veg}}(\mathrm{p}, \theta)=(1-\omega)(1-\mathrm{t}(\theta))\left(1+\mathrm{s}_{\text {soil }}(\mathrm{p}, \theta) \mathrm{t}(\theta)\right) \\
\mathrm{e}_{\mathrm{sky}}(\mathrm{p}, \theta)=0
\end{array}\right.
$$

where $\omega$ is the effective scattering albedo, $\mathrm{s}_{\text {soil }}$ is the reflectivity of the soil surface, function of $\mathrm{p}$ and $\theta$, and $t$ is the vegetation transmittivity which is function of the VOD ("VOD" and " $\tau$ " terms are equivalent, the latter term being used most often in RT models) and $\theta$.

For smooth surfaces, $\mathrm{s}_{\mathrm{soil}}$ is estimated as the Fresnel reflectivities of the soil surface at horizontal $(\mathrm{H})$ and vertical $(\mathrm{V})$ polarizations for an effective permittivity of the soil $\varepsilon_{\text {soil }}$, assuming the incidence angle $\theta$ is the same for the soil and the vegetation at the soil surface ("soft layer" approximation) as follows [64]:

$$
\left\{\begin{array}{c}
\mathrm{s}_{\text {soil }}(\mathrm{H}, \theta)=\left|\frac{\mathrm{A} \sqrt{\varepsilon_{\text {veg }}}-\mathrm{B} \sqrt{\varepsilon_{\text {soil }}}}{\mathrm{A} \sqrt{\varepsilon_{\mathrm{veg}}}+\mathrm{B} \sqrt{\varepsilon_{\text {soil }}}}\right|^{2} \\
\mathrm{~s}_{\text {soil }}(\mathrm{V}, \theta)=\left|\frac{\mathrm{A} \sqrt{\varepsilon_{\mathrm{veg}}}-\mathrm{B} \sqrt{\varepsilon_{\text {soil }}}}{\mathrm{A} \sqrt{\varepsilon_{\text {veg }}}+\mathrm{B} \sqrt{\varepsilon_{\text {soil }}}}\right|^{2}
\end{array}\right.
$$

with $\varepsilon_{\text {veg }}=\varepsilon_{\text {air }}=1, A=\cos \theta$ and $B=\sqrt{1-\left(1-\mathrm{A}^{2}\right) \varepsilon_{\text {veg }} / \varepsilon_{\text {soil }}}$

The vegetation transmittivity or vegetation attenuation factor is computed using the Beer's law:

$$
\mathrm{t}=\exp \left(-\frac{\tau}{\cos \theta}\right)
$$

Nevertheless, $\tau-\omega$ model does not simulate multiple reflections between the soil surface and the vegetation, inaccurately representing the coherent effects and multiple scattering in vegetation [65], so 
that volume scattering is not correctly accounted for in dense vegetation [66]. Enhancements were obtained overs forested areas through a fine tuning of $\omega$ and specific modelling of forest canopy [67-70]. Another solution is to consider higher order radiative transfer model to better describe the multiple reflections between the soil surface and the vegetation. The Two-Stream emission model (2S) is a first order radiative transfer model which holds a stronger physical background than the $\tau-\omega$ model as it takes into account multiple scattering and reflection and does not require the "soft layer" assumption [71]. This model was successfully applied to SMOS $\mathrm{T}_{\mathrm{B}}$ to inverse soil moisture (SM) and $\operatorname{VOD}($ i.e., $\tau)$ [72].

In 2S model, emiisvities are defined as [71]:

$$
\left\{\begin{array}{c}
e_{\text {soil }}(p, \theta)=\frac{1-s_{\text {soil }}(p, \theta)}{1-s_{\text {soil }}(p, \theta) r_{\text {veg }}(\theta)} t_{\text {veg }}(\theta) \\
e_{\text {veg }}(p, \theta)=\left(1-r_{v e g}(\theta)-t_{\text {veg }}(\theta)\right) \frac{1-s_{\text {soil }}(p, \theta) r_{\text {veg }}(\theta)+s_{\text {soil }}(p, \theta) t_{\text {veg }}(\theta)}{1-s_{\text {soil }}(p, \theta) r_{\text {veg }}(\theta)} \\
e_{\text {sky }}(p, \theta)=1-e_{\text {soil }}(p, \theta)-e_{\text {veg }}(p, \theta)
\end{array}\right.
$$

where $r_{v e g}$ and $t_{v e g}$ are the reflectivity and the transmissivity of the vegetation layer at the incidence $\theta$. In 2S, they are expressed as:

$$
\left\{\begin{array}{l}
\mathrm{r}_{\mathrm{veg}}(\theta)=\frac{\left(1+\sqrt{1-\omega^{2}}\right) \omega \exp \left(2 \tau \sqrt{1-\omega^{2}} / \cos \theta\right)}{\left(2-\omega^{2}+2 \sqrt{1-\omega^{2}}\right) \exp \left(2 \tau \sqrt{1-\omega^{2}} / \cos \theta\right)-\omega^{2}} \\
\mathrm{t}_{\mathrm{veg}}(\theta)=\frac{2\left(1-\omega^{2}+1 \sqrt{1-\omega^{2}}\right) \exp \left(2 \tau \sqrt{1-\omega^{2}} / \cos \theta\right)}{\left(2-\omega^{2}+2 \sqrt{1-\omega^{2}}\right) \exp \left(2 \tau \sqrt{1-\omega^{2}} / \cos \theta\right)-\omega^{2}}
\end{array}\right.
$$

Results obtained in [72] did not provide clear improvement in the VOD retrievals. For instance, very similar correlations with NDVI and biomass were obtained using VOD retrievals from the $\tau-\omega$ and $2 \mathrm{~S}$ models. However, the $2 \mathrm{~S}$ retrievals allowed to make a continuity between vegetation- and snow-covered land surfaces.

\subsection{VOD from Active Microwave Observations}

Numerous models were developed to simulate the radar backscattering of land surfaces in the active domain, VOD is one of the variable used to describe the backscattering of a land surface covered with vegetation. It is defined as follows using the water cloud model (WCM) [43,73]:

$$
\sigma^{0}=\sigma_{\text {veg }}^{0}+t^{2} \sigma_{\text {soil }}^{0}+\sigma_{\text {soil }+ \text { veg }}^{0}
$$

where $\sigma^{0}, \sigma_{\mathrm{veg}}^{0}, \sigma_{\text {soil }}^{0}$ and $\sigma_{\text {soil }}^{0}$ veg are the total backscattering of the land surface, the direct backscattering of the vegetation, the backscattering of the soil twice attenuated by the vegetation cover and the multiple scattering from soil-vegetation interactions. The vegetation transmittivity term is also defined using the Beer's law (9) as for the passive microwave case.

These different terms are expressed as:

$$
\left\{\begin{array}{c}
\sigma_{\text {soil }(\mathrm{dB})}^{0}=10 \log _{10}\left(\sigma_{\text {soil }}^{0}\right)=\mathrm{C}+\mathrm{D} \cdot \mathrm{SM} \\
\sigma_{\text {veg }}^{0}=\mathrm{AV}_{1}\left(1-\mathrm{t}^{2}\right) \cos (\theta)
\end{array}\right.
$$

The multiple scattering effects from the soil vegetation interactions $\left(\sigma_{\text {soil }+ \text { veg }}^{0}\right)$ are generally neglected as:

$$
\sigma_{\text {soil }+ \text { veg }}^{0} \ll \sigma^{0}
$$

The VOD (i.e., $\tau$ ) present in the vegetation transmittivity term is often written:

$$
\tau=\mathrm{BV}_{2}
$$


where $A, B, C, D, V_{1}$ and $V_{2}$ are parameters of the WCM model. The two latter ones represent the effect of the vegetation on the radar backscattering [74]. In the original formulation of the WCM, $\mathrm{V}_{1}$ equals to 1 [43]. In other studies, different variables were chosen for $V_{1}$ and $V_{2}$. For instance, several studies chose to use either the same vegetation-related variable (e.g., NDVI, LAI, VWC) for $\mathrm{V}_{1}$ and $\mathrm{V}_{2}$ [75-78] or different ones [79-81]. Another possibility is to set one of them to vegetation related variable and consider the other equals to a constant (e.g., $\mathrm{V}_{1}=1$ and $\mathrm{V}_{2}=\mathrm{LAI}$ as in [74]).

Other forms of WCM were developed. Changes in $\sigma_{\text {veg }}^{0}$ were proposed to better fit the responses measured at C- and L-bands. In this case, the backscattering of the vegetation is expressed as, using a new parameter $\mathrm{E}$ in the model [82]:

$$
\sigma_{\text {veg }}^{0}=\mathrm{AV}_{1}{ }^{\mathrm{E}}\left(1-\mathrm{t}^{2}\right) \cos (\theta)
$$

At higher frequencies, at $\mathrm{X}, \mathrm{Ku}$ and $\mathrm{Ka}$ bands, the vegetation backscattering is decomposed in two terms related to the leaf $\left(\sigma_{\text {leaf }}^{0}\right)$ stalk and the stalk $\left(\sigma_{\text {stalk }}^{0}\right)$ [73]. Equation (12) becomes:

$$
\sigma^{0}=\sigma_{\text {leaf }}^{0}+\sigma_{\text {stalk }}^{0}+t^{2} \sigma_{\text {soil }}^{0}
$$

with:

$$
\left\{\begin{aligned}
\sigma_{\text {leaf }}^{0}= & A_{\text {leaf }}\left(1-\exp \left(\frac{-B_{\text {leaf }} \mathrm{V}_{1}}{\mathrm{~h}_{\text {leaf }}}\right)\right)\left(1-\mathrm{t}_{\text {leaf }}{ }^{2}\right) \cos (\theta) \\
& \sigma_{\text {stalk }}^{0}=\mathrm{A}_{\text {stalk }} \mathrm{V}_{2} \frac{\mathrm{h}_{\text {stalk }}}{\mathrm{h}_{\text {leaf }}+\mathrm{h}_{\text {stalk }}} \mathrm{t}_{\text {stalk }}{ }^{2}
\end{aligned}\right.
$$

where $A_{\text {leaf }}, A_{\text {stalk }}$ and $B_{\text {stalk }}$ are model parameters, $h_{\text {leaf }}$ and $h_{\text {stalk }}$ are the height of the leaf and stalk layers respectively, and $t_{\text {leaf }}$ is transmissivity of the stalk layer.

The transmittivity for leaf and stalk are defined as:

$$
\left\{\begin{array}{c}
\mathrm{t}_{\text {leaf }}=\exp \left(-\alpha_{\text {leaf }} \mathrm{V}_{1} \sec (\theta)\right) \\
\mathrm{t}_{\text {slalk }}=\exp \left(-\frac{\alpha_{\text {slalk }} \mathrm{V}}{2}{ }_{2} \frac{\mathrm{h}_{\text {stalk }}}{\mathrm{h}_{\text {leaf }}+\mathrm{h}_{\text {stalk }}}\right)
\end{array}\right.
$$

where $\alpha_{\text {leaf }}$ and $\alpha_{\text {stalk }}$ are model parameters, determined using a non-linear regression minimizing the root-mean-square difference between modeled and observed backscattering coefficients.

\subsection{Global Long-Term VOD Products}

Several groups developed and, most of the time, made available global long-term VOD products obtained inversing passive microwave models.

1. The global land parameter data record (LPDR) [83]:

This dataset is produced using calibrated $\mathrm{T}_{\mathrm{B}}$ acquisitions from the Advanced Microwave Scanning Radiometer for EOS (AMSR-E) onboard the National Aeronautics and Space Agency (NASA) EOS Aqua satellite (05/2002-10/2011), and from the Advanced Microwave Scanning Radiometer 2 (AMSR2) onboard the Japan Aerospace Exploration Agency (JAXA) Global Change Observation Mission-Water1 (GCOM-W1) satellite (from 05/2012). VOD is retrieved from $T_{B}$ acquired by AMSR-E and AMSR2 at $\mathrm{X}$ band $(10.7 \mathrm{GHz})$ at $\mathrm{H}$ and $\mathrm{V}$ polarizations using $\tau-\omega$ model. $\mathrm{T}_{\mathrm{B}}$ are preprocessed to minimize the effects of RFI (radio frequency interference), precipitation, and permanent ice and snow cover using the flags defined in [84] and the freeze thaw status under frozen conditions [85]. Besides, the VOD is expressed as a function of the land-water emissivity slope index $\alpha$ as follows [86]:

$$
\tau=-\log \left(\frac{-B-\sqrt{B^{2}-4 A C}}{2 A}\right)
$$


with:

$$
\left\{\begin{array}{c}
\mathrm{A}=(1-\omega)\left(\mathrm{r}_{\text {dry }}(\theta, \mathrm{V})-\alpha \mathrm{r}_{\text {dry }}(\theta, \mathrm{H})\right) \\
\mathrm{B}=\alpha \mathrm{e}_{\text {dry }}(\theta, \mathrm{H})-\mathrm{e}_{\text {dry }}(\theta, \mathrm{V})+(1-\omega)\left(\alpha \mathrm{r}_{\text {dry }}(\theta, \mathrm{H})-\mathrm{r}_{\text {dry }}(\theta, \mathrm{V})+1-\alpha\right) \\
\mathrm{C}=(1-\omega)(\alpha-1)+\mathrm{e}_{\text {water }}(\theta, \mathrm{V})-\alpha \mathrm{e}_{\text {water }}(\theta, \mathrm{H}) \\
\alpha=\frac{\mathrm{e}(\theta, \mathrm{V})-\mathrm{e}_{\text {water }}(\theta, \mathrm{V})}{\mathrm{e}(\theta, \mathrm{H})-\mathrm{e}_{\text {water }}(\theta, \mathrm{H})}
\end{array}\right.
$$

where $e_{d r y}, e, e_{w a t e r}$ are the dry bare soil, land, and open water emissivities, $r_{d r y}$ is the bare soil reflectivity. All these parameters have predefined values except e [86]. $\omega$ is a constant set to 0.06 [87].

This dataset is made available by the University of Montana at [88].

2. Land Parameter Retrieval Model (LPRM) [89]:

This dataset is obtained from $\mathrm{T}_{\mathrm{B}}$ acquired by the:

- Scanning Multichannel Microwave Radiometer (SMMR) onboard Nimbus satellite at C (6.6 GHz), $\mathrm{X}(10.7 \mathrm{GHz})$ and $\mathrm{Ku}(18 \mathrm{GHz})$ bands at $\mathrm{H}$ and $\mathrm{V}$ polarizations over 11/1978-08/1987,

- Special Sensor Microwave/Imager (SSM/I) onboard Defense Meteorological Satellite Program (DMSP) at K (19.35 GHz) bands at $\mathrm{H}$ and V polarizations over 07/1987-04/2015,

- Tropical Rainfall Measuring Mission (TRMM) Microwave Imager (TMI) onboard TRMM satellite at $\mathrm{X}(10.65 \mathrm{GHz})$ at $\mathrm{H}$ and $\mathrm{V}$ polarizations over 12/1997-04/2015,

- AMSR-E at C $(6.93 \mathrm{GHz}), \mathrm{X}(10.65 \mathrm{GHz})$ and $\mathrm{K}(18.7 \mathrm{GHz})$ bands at $\mathrm{H}$ and $\mathrm{V}$ polarizations over 05/2002-10/2011,

- WindSat onboard Coriolis satellite at C (6.8 GHz), X (10.7 GHz) and $\mathrm{Ku}(18.7 \mathrm{GHz})$ bands at H and V polarizations over 02/2003-07/2012,

- $\quad$ AMSR2 at C (6.93 and 7.3 GHz), X (10.65 GHz) and $\mathrm{K}(18.7 \mathrm{GHz})$ bands at $\mathrm{H}$ and V polarizations from $05 / 2012$,

Using the $\tau-\omega$ model [90]. Only nighttime $T_{B}$ are used as they are supposed to be less affected by lower temperature-related error because the soil and vegetation media are closer to equilibrium at night than during the day [90]. A threshold approach was developed to filter out data exhibiting differences between observed and simulated $\mathrm{T}_{\mathrm{B}}$ higher than $0.25 \mathrm{~K}$. These data correspond to grid points with frozen soil conditions, snow cover or excessive vegetation [91]. VOD is expressed as a function of the microwave polarization difference index (MPDI), which is frequently used to remove the temperature dependence of $\mathrm{T}_{\mathrm{B}}$, as follows [92]:

$$
\tau=\mathrm{C}_{1} \ln \left(\mathrm{C}_{2} \mathrm{MPDI}+\mathrm{C}_{3}\right)
$$

with:

$$
\text { MPDI }=\frac{T_{B}(\theta, V)-T_{B}(\theta, H)}{T_{B}(\theta, V)+T_{B}(\theta, H)}
$$

The coefficients $C_{i}$ are polynomial functions absolute value of the soil dielectric constant [92].

This dataset is made available by the Vrije University Amsterdam (VUA) and National Aeronautics and Space Administration (NASA) at [93].

3. Global Long-term Microwave Vegetation Optical Depth Climate Archive (VODCA) [94]:

VODCA is an approach developed to combine multiple VOD datasets, derived from multiple sensors (SSM/I, TMI, AMSR-E, Windsat, and AMSR-2), that have in common to have been processed using LPRM [90,92]. The merging approach is composed of three steps ) [94]:

- a preprocessing to identify and remove potentially noisy data using the Radio Frequency Interference (RFI) flag proposed by [95] and used for Climate Change Initiative (CCI) SM 
products [96], land surface temperature (LST), derived from $\mathrm{T}_{B}$ acquired at Ka band [97] by the same sensors, below $0{ }^{\circ} \mathrm{C}$ corresponding to a frozen soil and negative VOD.

- a co-calibration based on matching of a cumulative distribution function (CDF) on a per-pixel basis using AMSR-E VOD as the scaling reference for the different frequencies, similarly to what was done for ESCA CCI SM [96].

- an aggregation of the datasets averaging the temporally overlapping observations of the scaled data. This dataset is made available by the Technical University of Wien and Vandersat at [98].

\section{Soil Moisture and Ocean Salinity (SMOS)-INRA-CESBIO (IC) [99]:}

This dataset is retrieved from $\mathrm{T}_{\mathrm{B}}$ acquired by SMOS at $\mathrm{L}$ band $(1.4 \mathrm{GHz})$ at $\mathrm{H}$ and $\mathrm{V}$ polarizations, from 12/2009, using the L-MEB model inversion approach in the $\tau-\omega$ [99] and 2S [72] versions. RFI are filtered using multiple thresholds on daily annual $T_{B}$ RSME and time variations of the VOD on each pixel. Surface conditions flags are also applied to detect the presence of strong topography, water bodies, urban areas, ice and frozen conditions. $\operatorname{VOD}(\tau)$ and soil moisture $(\mathrm{SM})$ are simultaneously derived from the inversion of the L-band microwave emission of the biosphere (L-MEB) model [99-101]. Each pixel is considered as entirely homogeneous for the inversion process. VOD is expressed as:

$$
\tau(\theta, p)=\tau\left(0^{\circ}, p\right) \ln \left(t t(p) \sin ^{2}(\theta)+\cos ^{2}(\theta)\right)
$$

where $\mathrm{tt}$ is a parameter function of the canopy type.

The retrieval of SM and VOD requires the minimization of the following cost function F:

$$
\mathrm{F}=\frac{\sum_{\mathrm{p}=\mathrm{H}}^{\mathrm{p}=\mathrm{V}}\left(\sum_{\mathrm{i}=1}^{\mathrm{N}}\left(\mathrm{T}_{\mathrm{B}}{ }^{\text {obs }}\left(\mathrm{p}, \theta_{\mathrm{i}}\right)-\mathrm{T}_{\mathrm{B}}{ }^{\text {model }}\left(\mathrm{p}, \theta_{\mathrm{i}}\right)\right)^{2}\right)}{\sigma\left(\mathrm{T}_{\mathrm{B}}\right)^{2}}+\frac{\left(\mathrm{SM}_{\mathrm{ini}}-\mathrm{SM}\right)^{2}}{\sigma^{2}(\mathrm{SM})}+\frac{\left(\tau_{\text {ini }}-\tau\right)^{2}}{\sigma^{2}(\tau)}
$$

where $\mathrm{N}$ is the number of valid SMOS observations for a given pixel, obs and model refer to measured and modeled respectively, $\mathrm{SM}_{\mathrm{ini}}$ and $\tau_{\text {ini }}$ are the initialization values for SM and $\tau$ respectively. $\sigma^{2}(\mathrm{X})$ is the variance of the retrieved parameter $\mathrm{X}(\mathrm{X}=\mathrm{SM}$ or VOD).

This dataset is made available as a scientific product (not as official product) by Centre de Traitement Aval des Données SMOS (CATDS), the French ground segment for the SMOS Level 3 and Level 4 data at [102] and by Institut National de Recherche pour l'Agriculture, l'Alimentation et $l^{\prime}$ Environnement (INRAE) BORDEAUX remote sensing products at [103].

\section{SMOS Level 2 [104]:}

This dataset is obtained through the inversion the $T_{B}$ acquired by Microwave Imaging Radiometer using Aperture Synthesis (MIRAS) on board the European Space Agency (ESA) SMOS mission at L band $(1.4 \mathrm{GHz})$ at $\mathrm{H}$ and $\mathrm{V}$ polarizations, from $12 / 2009$, using the $\tau$ - $\omega$ model. Thresholds and 2-sigma criteria are applied on the $T_{B}$ to filter out invalid data (see [105] for a detailed description of these criterion). A RFI flag, based on a modelling approach of these interferences, is applied to mask the contaminated pixels [106]. Corrections of the direct solar radiations are also applied [107]. Due to the coarse resolution of the SMOS data (between 25 and $60 \mathrm{~km}$ ), soil and vegetation are not uniform inside a pixel. Each pixel $\mathrm{T}_{\mathrm{B}}$ is the sum of the emission of each vegetation and soil type class weighted by its intra-pixel cover fraction. A window of $123 \mathrm{~km} \times 123 \mathrm{~km}\left(35 \times 35\right.$ elementary cells of $\left.\sim 4 \mathrm{~km}^{2}\right)$ for every node is defined to take into account all the contributions, weighted by the SMOS antenna pattern, to the observed $\mathrm{T}_{\mathrm{B}}$. External information on land cover allows to identify the main vegetation type-low vegetation (grasslands, crops, shrubs, savannas, etc.) and forest (coniferous, and broadleaf)—contributing in each pixel. The type of inversion model that should be used on the dominant fraction is selected depending on the surface conditions using a decision tree [104]. The contribution of the other fraction (such as forests, forested areas, barren land (rocks), water bodies, urban areas, permanent ice, and snow) is corrected from the observed $\mathrm{T}_{\mathrm{B}}$ using a dedicated model and external information [104]. 
VOD at nadir $\left(\theta=0^{\circ}\right)$ are given by:

For low vegetation:

$$
\tau\left(0^{\circ}, p\right)=b_{s}^{\prime} L A I+b_{s}^{\prime \prime}
$$

where $b_{\mathrm{s}}^{\prime}$ and $b_{\mathrm{s}}^{\prime \prime}$ are parameters function of the canopy type.

For forests:

$$
\tau\left(0^{\circ}, \mathrm{p}\right)=\mathrm{b}_{\mathrm{F}}^{\prime} \mathrm{LAI}_{\mathrm{Fmax}}+\mathrm{b}_{\mathrm{v}} \mathrm{LAI}_{\mathrm{V}}
$$

where $b_{\mathrm{F}}^{\prime}$ and $b_{\mathrm{V}}$ are parameters function of the forest type, $\mathrm{LAI}_{\mathrm{Fmax}}$ is the maximum yearly value of arboreous LAI, and $\mathrm{LAI}_{\mathrm{v}}$ is the time-dependent contribution of low vegetation. VOD and $\mathrm{SM}$ are simultaneously inverted minimizing the cost function from L-MEB (25).

Moderate Resolution Imaging Spectroradiometer (MODIS) LAI is used in the L2 retrieval process in two ways: (1) to initialize the VOD retrievals through the $\tau_{\text {ini }}$ term in Equation (26) and to compute VOD for the non-dominant fraction in heterogeneous pixels. These constraints make SMOS L2 VOD (and L3 VOD described below) as not independent of optical observations (e.g., MODIS LAI), contrary to the SMOS-IC approach which allows independent evaluations/applications in combination with optical EO observations.

This dataset is made available by ESA SMOS Online Dissemination Service at [108].

\section{SMOS Level 3 [105]:}

The SMOS Level 3 retrieval is based on the same physical approach as SMOS Level 2 but taking into account several orbits to benefit from the longer temporal autocorrelation length of the VOD compared to SM [105]. The same preprocessing as Level 2 is performed (see SMOS Level 2 description). Retrievals are performed considering three revisits over a 7-day temporal window minimizing the following cost function expressed as:

$$
\begin{aligned}
& \mathrm{F}=\left(\mathrm{T}_{\mathrm{B}}{ }^{\text {obs }}(\mathrm{p}, \theta)-\mathrm{T}_{\mathrm{B}}{ }^{\text {model }}(\mathrm{p}, \theta)\right)^{\mathrm{p}} \operatorname{cov}\left(\mathrm{T}_{\mathrm{B}}\right)^{-1}\left(\mathrm{~T}_{\mathrm{B}}{ }^{{ }^{\mathrm{obs}}}(\mathrm{p}, \theta)-\mathrm{T}_{\mathrm{B}}{ }^{\text {model }}(\mathrm{p}, \theta)\right) \\
& +\left(\tau-\tau^{0}\right)^{\mathrm{p}} \operatorname{cov}(\tau)^{-1}\left(\tau-\tau^{0}\right)+\left(\mathrm{SSM}-\mathrm{SSM}^{0}\right)^{\mathrm{p}} \operatorname{cov}(\mathrm{SSM})^{-1}\left(\mathrm{SSM}-\mathrm{SSM}^{0}\right)
\end{aligned}
$$

with:

$$
\left\{\begin{array}{c}
\operatorname{cov}\left(\mathrm{T}_{\mathrm{B}}\right)=\sigma^{2}\left(\mathrm{~T}_{\mathrm{B}}\right) \\
\operatorname{cov}(\mathrm{SSM})=\sigma^{2}\left(\mathrm{SSM}^{0}\right) \mathrm{I}_{3} \\
\operatorname{cov}(\tau)=\sigma^{2}\left(\tau^{0}\right)\left(\begin{array}{ccc}
1 & \rho\left(\mathrm{t}_{\mathrm{c}}, \mathrm{t}_{\mathrm{i}}\right) & \rho\left(\mathrm{t}_{\mathrm{f}}, \mathrm{t}_{\mathrm{i}}\right) \\
\rho\left(\mathrm{t}_{\mathrm{i}}, \mathrm{t}_{\mathrm{t}}\right) & 1 & \left(\mathrm{t}_{\mathrm{f}}, \mathrm{t}_{\mathrm{c}}\right) \\
\left(\mathrm{t}_{\mathrm{i}}, \mathrm{t}_{\mathrm{f}}\right) & \left(\mathrm{t}_{\mathrm{c}}, \mathrm{t}_{\mathrm{f}}\right) & 1
\end{array}\right)
\end{array}\right.
$$

where $X^{0}$ is the initial value of the parameter $X, \operatorname{cov}\left(T_{B}\right)$ is the error covariance matrix of $T_{B}$ data assuming no temporal autocorrelation, $\sigma^{2}\left(\mathbf{X}^{0}\right)$ is the variance of $X^{0}, I_{3}$ is the $3 \times 3$ identity matrix, $t_{i}$, $t_{c}$ and $t_{f}$ are the initial, central and final times respectively in the 7-day temporal window, $\rho$ is the correlation function modeled assuming a Gaussian distribution of the autocorrelation:

$$
\rho\left(t_{1}, t_{2}\right)=\rho_{\max }\left(t_{1}, t_{2}\right) \exp \left(-\frac{\left(t_{1}, t_{2}\right)^{2}}{T_{c}{ }^{2}}\right)
$$

where $\rho_{\max }$ is the maximum of the correlation function between the instants $t_{1}$ and $t_{2}$, and $T_{c}$ is the VOD characteristic correlation time. $T_{c}$ is set to 10 days over low vegetation and 30 days over forests.

This dataset is made available as the official L3 product by CATDS at [102].

7. SMAP Level 2 Passive Soil Moisture Product (L2_SM_P) [109] and SMAP Level 2 Enhanced Passive Product (L2_SM_P_E) [110]:

These datasets are retrieved from the $\mathrm{T}_{\mathrm{B}}$ acquired by the NASA Soil Moisture Active Passive (SMAP) satellite at $\mathrm{L}$ band $(1.41 \mathrm{GHz})$ at $\mathrm{H}$ and $\mathrm{V}$ polarizations from $04 / 2015$ using the $\tau-\omega$ model. 
The high quality $\mathrm{T}_{\mathrm{B}}$ acquisitions are RFI-filtered using the approach presented in [111]. Data are checked for the presence of water, urban, precipitation, frozen ground, snow and ice fractions, as well as Digital Elevation Model (DEM) statistics [109,110]. The same processing is used for both products but in the case of L2_SM_P applied to the SMAP T $\mathrm{T}_{\mathrm{B}}$ at $36 \mathrm{~km}$ of spatial resolution and in the case of L2_SM_EP Backus-Gilbert enhanced $\mathrm{T}_{\mathrm{B}}$ [110] at $9 \mathrm{~km}$ of spatial resolution. Among the five algorithms implemented to invert SM, only three of them also provide a VOD product: the Dual Channel Algorithm (DCA), the Microwave Polarization Ratio Algorithm (MPRA) based on the LPRM algorithm [92] and the Extended Dual Channel Algorithm (E-DCA). The DCA takes advantage of the complementary information contained in $\mathrm{T}_{\mathrm{B}}$ at $\mathrm{H}$ and $\mathrm{V}$ polarizations to retrieve SM and VOD assuming that the VOD value is the same for the $\mathrm{H}$ and $\mathrm{V}$ polarizations [112], minimizing the following cost function:

$$
F=\left(T_{B}{ }^{o b s}(V)-T_{B}{ }^{\text {model }}(V)\right)^{2}+\left(T_{B}{ }^{o b s}(H)-T_{B}{ }^{\text {model }}(H)\right)^{2}
$$

The E-DCA consists in minimizing the following cost function:

$$
\begin{aligned}
& F=\left(\log \left(\frac{T_{B}{ }^{o b s}(V)-T_{B}{ }^{o b s}(H)}{T_{B}{ }^{o b s}(V)+T_{B}{ }^{o b s}(H)}\right)-\log \left(\frac{T_{B}{ }^{\text {model }}(V)-T_{B}{ }^{\text {model }}(H)}{T_{B}{ }^{\text {model }}(V)+T_{B}{ }^{\text {model }}(H)}\right)\right)^{2} \\
& +\left(\log \left(T_{B}{ }^{o b s}(H)\right)-\log \left(T_{B}{ }^{\text {model }}(H)\right)\right)^{2}
\end{aligned}
$$

A modified version of DCA was recently implemented-the modified DCA (MDCA) [113]. Compared with DCA, MDCA is based on the determination of values of the roughness parameter $\left(\mathrm{h}_{\mathrm{r}}\right)$ and of the polarization mixing parameter $(\mathrm{Q})$ that are used to model the soil roughness reflectivity. To determine $h_{r}$, a temporary $h_{r}{ }^{\prime}$ is considered in (34) instead of VOD. This operation was performed for all SMAP $\mathrm{T}_{B}$ acquired in 2017 using the NDVI as a proxy for the VOD. For any gridpoint of coordinates $(\mathrm{i}, \mathrm{j})$, considering $\mathrm{k}$ SMAP acquisitions during the considered period, $\mathrm{h}_{\mathrm{r}}$ is equal to:

$$
h_{r}(i, j)=\operatorname{average}\left(h_{r}^{\prime}\left(i, j, k^{\prime}\right)\right.
$$

for all the $\mathrm{k}^{\prime}$ verifying the following condition:

$$
\tau\left(i, j, k^{\prime}\right) \leq \min _{\text {all } k} \tau(i, j, k)+f\left(\max _{\text {all } k} \tau(i, j, k)-\min _{\text {all } k} \tau(i, j, k)\right)
$$

where $\mathrm{f}$ is set 0.05 to reflect the impact of local minimum of vegetation activity on $\mathrm{h}_{\mathrm{r}}{ }^{\prime}$ but excluding this minimum [113].

$\mathrm{Q}$ is proportional to $\mathrm{h}_{\mathrm{r}}$ based on numerical solutions of Maxwell's equations for EM for the scattering model of a rough surface at $\mathrm{L}$ band [114]:

$$
Q(i, j)=0.1771 h_{r}(i, j)
$$

These datasets are made available by the Jet Propulsion Laboratory at [115].

8. Multi-temporal dual-channel retrieval algorithm (MT-DCA) [116]:

This dataset is retrieved from $T_{B}$ acquired by the NASA SMAP satellite at $\mathrm{L}$ band $(1.41 \mathrm{GHz})$ at $\mathrm{H}$ and $V$ polarizations from $04 / 2015$ using the $\tau-\omega$ model. MT-DCA is applied to SMAP Backus-Gilbert enhanced $T_{B}[110]$ to derive soil moisture and VOD as well as effective scattering albedo $(\omega)$ [117]. The three parameters are obtained using a combination of $T_{B}$ from two consecutive overpasses, assuming VOD is constant during the corresponding time period, and minimizing the following cost function:

$$
\mathrm{F}(\mathrm{X})_{\mathrm{X}=\mathrm{SM}_{1,1} \operatorname{VOD}}=\sum_{\mathrm{p}=\mathrm{H}}^{\mathrm{p}=\mathrm{V}}\left(\sum_{\mathrm{i}=1}^{\mathrm{N}}\left(\mathrm{T}_{\mathrm{B}}{ }^{\mathrm{obs}}(\mathrm{p}, \theta)-\mathrm{T}_{\mathrm{B}}{ }^{\text {model }}(\mathrm{p}, \theta)\right)^{2}\right)
$$


This approach can be applied to $\mathrm{N}$ overpasses as long as the assumption of constant VOD remains valid. Two overpasses are used to increase the liability of the constant VOD assumption [116].

This dataset is made available by Stanford University at [118].

9. Metop-A ASCAT VOD from Technische Universität (TU) Wien [119]:

This dataset is obtained through the inversion of $\sigma^{0}$ acquired at $\mathrm{C}$ band $(5.255 \mathrm{GHz})$ at $\mathrm{V}$ polarization by the Advanced Scatterometer (ASCAT) sensors onboard the EUMETSAT MetOp-A and B satellites launched in September 2006 and October 2012 respectively, using the WCM model. VOD is given by [119]:

$$
\tau(\theta)=\frac{\cos (\theta)}{2} \ln \left(\frac{\Delta \sigma_{s}^{0}}{\Delta \sigma^{0}}\right)
$$

where $\Delta \sigma_{\mathrm{s}}^{0}$ represents the maximum range in backscatter values over bare soils due to a change in soil moisture, assumed to be constant through time. And $\Delta \sigma^{0}$ is the difference between the wet and dry references which are calculated from the historically wettest and driest backscatter measurements at $\theta$ equals $40^{\circ}$ [120]. Temporal variations of the VOD were introduced using a second-order Taylor expansion for the dry reference for incidence angles not equal to $40^{\circ}$ [119]:

$$
\sigma^{0}(\theta, \mathrm{t})=\sigma^{0}(40, \mathrm{t})+\sigma^{\prime}(40, \mathrm{DOY})(\theta-40) \frac{\pi}{180}+\frac{1}{2} \sigma^{\prime \prime}(40, \text { DOY })(\theta-40)^{2}\left(\frac{\pi}{180}\right)^{2}
$$

where $\sigma^{\prime}$ and $\sigma^{\prime \prime}$ are the slope and the curvature, respectively average every day of the year (DOY) over several years.

The characteristics of the VOD products presented above are summarized in Table 2.

\section{Results and Applications}

\subsection{Experimental and Theoretical Studies}

Experimental studies achieved at field scale revealed the linear relationship between VOD and the vegetation water content (VWC) [51,121]. A semi-empirical relationship between VOD and VWC depending on the microwave frequency and the vegetation structure was established by Jackson and Schmugge [122]. VOD, canopy biomass and associated water content were found to be related by a general power-law response depending on the microwave frequency $[121,123]$. Then other relationships have been computed between VOD and sapflow [124], leaf water potential [51,125], vegetation structure [126-128], leaf fall [129] and LAI [100,130,131]. VOD was identified as a good proxy for estimating biomass and detecting water status of agricultural crops [131]. These relationships are presented in Table 3.

To complement these field studies, the relative contribution of different components of the vegetation to the VOD value was modelled $[70,132]$, and the transparency of the vegetation layer in a wide range of frequencies from $\mathrm{L}$ to Ka-bands and for different forest types was analyzed [133]. 
Table 2. Characteristics of the global long-term VOD products.

\begin{tabular}{|c|c|c|c|c|c|c|c|}
\hline Product & Sensor & Frequency (GHZ) & Spatial Resolution & Temporal Resolution & Period of Availability & Reference & Website \\
\hline \multirow{2}{*}{ LPDR Version 2} & \multirow{2}{*}{ AMSR-E, AMSR2 } & 10.65 & $25 \mathrm{~km}$ & daily & $01 / 2002-12 / 2011$ & \multirow[t]{2}{*}{ [83] } & \multirow{2}{*}{ [88] } \\
\hline & & 10.65 & $25 \mathrm{~km}$ & daily & since $05 / 2012$ & & \\
\hline \multirow{6}{*}{ LPRM Version 5} & SSMR & $6.63,10.69$ & $25 \mathrm{~km}$ & daily & 10/1978-02/1995 & \multirow{7}{*}{ [89] } & \multirow{6}{*}{ [93] } \\
\hline & $\mathrm{SSM} / \mathrm{I}$ & 19.35 & $25 \mathrm{~km}$ & daily & since 06/1987 & & \\
\hline & TMI & $10.65,19.35$ & $45 \mathrm{~km}$ & daily & 12/1997-04/2015 & & \\
\hline & AMSR-E & $6.925,10.65,18.7$ & $38,56 \mathrm{~km}$ & daily & 06/2002-10/2011 & & \\
\hline & Windsat & $6.8,10.7,18.7$ & $25 \mathrm{~km}$ & daily & $01 / 2003-07 / 2012$ & & \\
\hline & AMSR2 & $6.925,7.30,10.65,18.7$ & $31,46 \mathrm{~km}$ & daily & since 05/2012 & & \\
\hline \multirow{5}{*}{$\begin{array}{l}\text { VODCA (LPRM } \\
\text { Version 6) }\end{array}$} & $\mathrm{SSM} / \mathrm{I}$ & 19.35 & $0.25^{\circ}$ & daily & since $06 / 1987$ & & \multirow{5}{*}{ [94] } \\
\hline & TMI & $10.65,19.35$ & $0.25^{\circ}$ & daily & 12/1997-04/2015 & \multirow{4}{*}{ [94] } & \\
\hline & AMSR-E & $6.925,10.65,18.7$ & $0.25^{\circ}$ & daily & $06 / 2002-10 / 2011$ & & \\
\hline & Windsat & $6.8,10.7,18.7$ & $0.25^{\circ}$ & daily & since $01 / 2003$ & & \\
\hline & AMSR2 & $6.925,7.30,10.65,18.7$ & $0.25^{\circ}$ & daily & 05/2012-12/2019 & & \\
\hline SMOS L2 & SMOS & 1.4 & $25 \mathrm{~km}$ & daily & since $0 / 12010$ & [104] & [108] \\
\hline SMOS L3 & SMOS & 1.4 & $25 \mathrm{~km}$ & daily & since $0 / 12010$ & [105] & [102] \\
\hline SMOS-IC & SMOS & 1.4 & $25 \mathrm{~km}$ & daily & since $0 / 12010$ & [99] & {$[102,103]$} \\
\hline L2_SM_P & SMAP & 1.413 & $36 \mathrm{~km}$ & daily & since $02 / 2015$ & [109] & [115]. \\
\hline L2_SM_P_E & SMAP & 1.413 & $9 \mathrm{~km}$ & daily & since $02 / 2015$ & [110] & [115]. \\
\hline MT-DCA & SMAP & 1.413 & $9 \mathrm{~km}$ & daily & since $02 / 2015$ & [116] & [118] \\
\hline ASCAT TUW & ASCAT & 5.255 & $25 \mathrm{~km}$ & daily & since $10 / 2006$ & [119] & Not Available \\
\hline
\end{tabular}

Table 3. Relationships obtained from experimental and theoretical studies.

\begin{tabular}{|c|c|c|}
\hline Equations & Parameters & References \\
\hline $\begin{array}{c}\tau=\text { bVWC } \\
(40)\end{array}$ & b: vegetation parameter function of canopy type/structure, polarization $(\mathrm{H}$ or $\mathrm{V})$, and wavelength & {$[51,121]$} \\
\hline $\begin{array}{c}b=b^{\prime} \lambda^{x} \\
(41)\end{array}$ & $\begin{array}{l}\mathrm{b}^{\prime} \text { : wavelength-independent vegetation parameter } \\
\text { x: a power factor }\end{array}$ & [122] \\
\hline $\begin{array}{c}\tau=\mathrm{A}_{1} \sec (\theta) /(3 \lambda) \times 10^{-5} \mathrm{QM}_{\mathrm{g}} \varepsilon^{\prime \prime} \\
(42) \\
\tau=\mathrm{A}_{2} \mathrm{fVWC} \varepsilon^{\prime \prime} / \cos (\theta) \\
(43)\end{array}$ & $\begin{array}{l}\mathrm{A}_{1}, \mathrm{~A}_{2}: \text { structure parameters related to the geometry of the vegetation } \\
\text { Q: dry biomass } \\
\mathrm{M}_{\mathrm{g}} \text { : vegetation moisture content } \\
\varepsilon^{\prime \prime} \text { : imaginary part of the water permittivity }\end{array}$ & {$[121,123]$} \\
\hline $\begin{array}{c}\tau_{\text {res dry }}=a_{1} S+b_{1} \\
(44) \\
\text { with } \tau_{\text {res }}=\tau_{\text {modl }}-\tau_{\text {meas }}=\tau_{\text {res wet }}+\tau_{\text {res dry }} \\
(45)\end{array}$ & $\begin{array}{c}\tau_{\text {res dry }}: \text { dry residual VOD } \\
\text { S: sapflow } \\
\tau_{\text {res }}, \tau_{\text {model }}, \tau_{\text {meas }}, \tau_{\text {res wet }}: \text { residual, modelled, measured, and residual due to the water film on the leaves VOD, respectively }\end{array}$ & [124] \\
\hline$\tau=\mathrm{k} \lambda^{-1 / 2} \ln (1+\mathrm{VWC})=\mathrm{k} \lambda^{-1 / 2}$ RLAI & $\begin{array}{l}k: \text { crop factor } \\
\text { R: experimental correlation factor between LAI and Q determined during the first part of the plant's life cycle }\end{array}$ & {$[130,131]$} \\
\hline
\end{tabular}




\subsection{Evaluation of the VOD Products}

VOD represents the extinction effects of the microwave signals by the vegetation layer. Spatial patterns of VOD at different frequencies were found to be very similar as the ones of land cover $[116,134,135]$. Comparisons between VOD and vegetation-related parameters, such as NDVI, LAI, AGB and tree heights were performed to assess its representativeness. An early evaluation of VOD at $\mathrm{C}$ and Ka bands from SMMR acquisitions showed a good agreement with NDVI from the Advanced Very High Resolution Radiometer (AVHRR) over three years [136]. A comparison between VOD from LPRM (SSM/I and TMI T $T_{B}$ acquired at C band, AMSR-E also at $C$ band except over areas with moderate and strong RFI at $6.9 \mathrm{GHz}$ and NDVI from AVHRR over land surfaces, at monthly temporal resolution from 1987 to 2006 was achieved. Over these areas, $T_{B}$ acquired at $X$ band were incorporated to replace RFI-contaminated $\mathrm{T}_{\mathrm{B}}$ at $\mathrm{C}$-band applying the CDF matching technique [137]). A good correspondence was generally observed between the seasonal cycles and interannual variations from both products. Some non-negligible differences were found considering long-term trends [89]. AMSR-E VOD from LPDR at K band was compared to NDVI, Enhanced Vegetation Index (EVI) [20] and LAI [138] derived from Moderate Resolution Imaging Spectroradiometer (MODIS) multispectral reflectance data. Good correspondences $(p<0.01)$ between VOD and EVI, NDVI and LAI were found over $82 \%$ of the land surfaces. Higher correlations were observed over lower biomass land classes such as savannas $(R=0.66)$ than for higher biomass levels $(0.03<R<0.51)$. Better correlations were obtained for homogeneous land cover areas $(0.41<\mathrm{R}<0.83)$ than inhomogeneous ones [134]. AMSR-E VOD from LPRM version 5 product at $C$ band, substituted by VOD at $X$ band for moderate to strong RFI using the same approach as in [89], and SMOS Level 2 VOD at L band were compared to different indices derived from MODIS, at a temporal resolution of 15 days in 2010. Spatial and temporal linear (Pearson) and non-linear (Spearman) correlations were estimated between VOD and NDVI, EVI, LAI, and Normalized Difference Water Index (NDWI) [139]. VOD at C-band (C-VOD) from AMSR-E exhibited higher correlation with VI than with VOD at L-band (L-VOD) from SMOS (Spearman's R of 0.80 between C-VOD and L-VOD) at global scale [140]. Significant correlations between SMOS Level 2 L-VOD and NDVI, EVI, LAI and NDWI from MODIS were also found over crop zones of the USA in 2010-2011 [141]. Further studies using L-VOD periods of several years showed that the temporal correlation between SMOS L-VOD and NDVI MODIS are good for L-VOD lower than 0.7. For higher values of L-VOD corresponding to equatorial forests, NDVI tends to saturate [72,99] and correlation with L-VOD becomes non-significant as it can be seen in Figure 3a. In the active microwave domain, comparisons were made between ASCAT VOD from TU Wien and LAI from SPOT VEGETATION over Australia between 2007 and 2014. Similar spatial patterns were observed for SM, VOD and LAI. Contrasted results were obtained depending on the land class types. Higher correlation values between VOD and LAI were obtained over sparse vegetation areas in central Australia with R values of 0.78 and 0.58 respectively [120]. At higher spatial resolution $(10 \mathrm{~m})$, medium to good correlations were obtained between VOD at C-band from Sentinel-1 SAR images and NDVI derived from Sentinel-2 multispectral images over barley, fallow, oat, and wheat $\left(R^{2}\right.$ ranging from 0.39 and 0.61) [142].

Strong relationships were also identified between VOD, AGB, and tree heights. The following function was proposed to relate VOD to AGB [143]:

$$
A G B=a_{1} \frac{\arctan \left(b_{1}\left(\tau-c_{1}\right)\right)-\arctan \left(b_{1}\left(0-c_{1}\right)\right)}{\arctan \left(b_{1}\left(\infty-c_{1}\right)\right)-\arctan \left(b_{1}\left(0-c_{1}\right)\right)}+d_{1}
$$

as well as a logistic function [144]:

$$
\mathrm{AGB}=\frac{\mathrm{a}_{2}}{1+\exp \left(-\mathrm{b}_{2}\left(\tau-\mathrm{c}_{2}\right)\right)}+\mathrm{d}_{2}
$$

where $\mathrm{a}_{1}, \mathrm{~b}_{1}, \mathrm{c}_{1}, \mathrm{~d}_{1}, \mathrm{a}_{2}, \mathrm{~b}_{2}, \mathrm{c}_{2}$, and $\mathrm{d}_{2}$ are determined to best-fit the point distribution. 


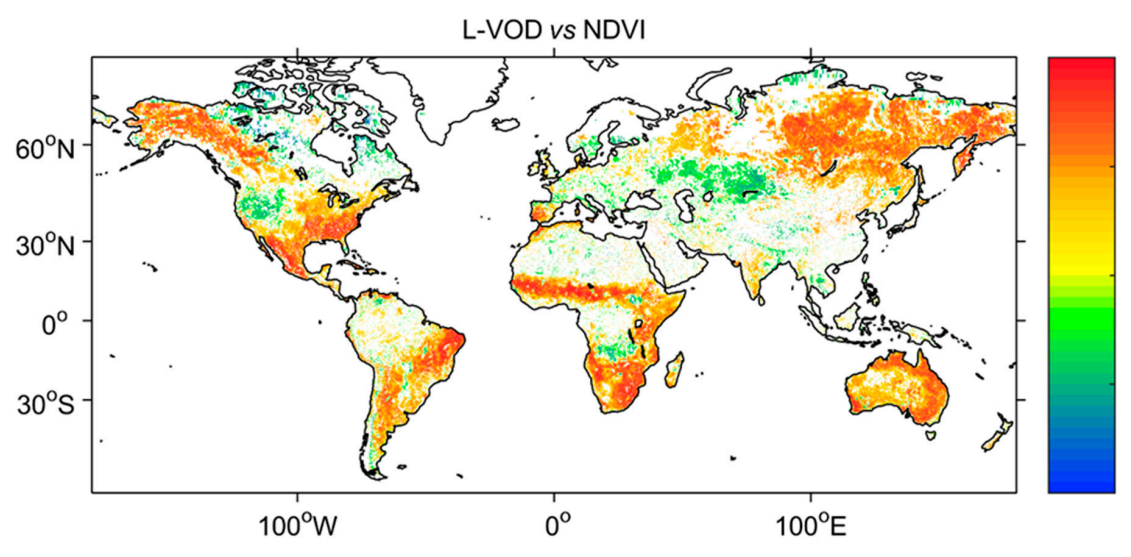

(a)

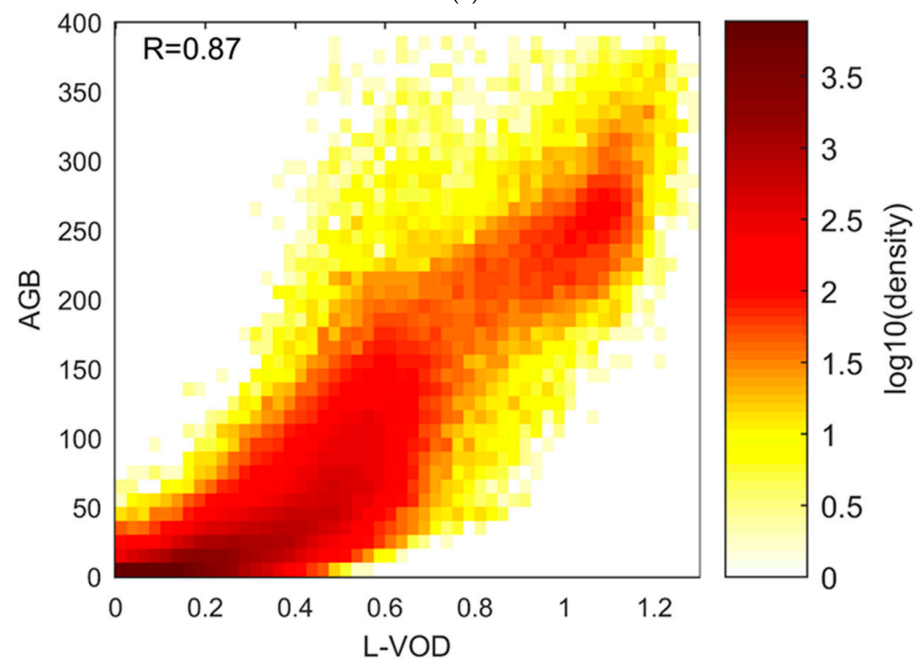

(b)

Figure 3. (a) Pixel-based temporal correlation (R) for the relationship between 16-day average values of SMOS-IC L-VOD and Moderate Resolution Imaging Spectroradiometer (MODIS) normalized difference vegetation index (NDVI). Grey areas correspond to pixels where correlation is not significant as defined by a $p$-value $>0.05$. White areas indicate "no valid data"; (b) Density scatter plots showing the spatial relationship between temporal mean of retrieved SMOS-IC L-VOD with above-ground biomass above ground biomass (AGB) values from [145] at global scale. Adapted from [72].

Determination coefficients between VOD data and AGB from either [145-148] are higher than 0.85 at regional to global scales $[72,143,144,149,150]$ from C- to L-bands (see an example of a calibration relationship between AGB from [145] and L-VOD from SMOS-IC in Figure 3b). VOD at C- and X-bands from LPRM and AGB were found almost linearly related for VOD value below 0.7. For higher VOD values, biomass increases non-linearly with VOD until a saturation of the VOD is reached for the higher biomass values [143]. This saturation is not observed at $\mathrm{L}$ band $[72,144]$. Lower agreement were found when considering a linear relationship between VOD from C to L bands and AGB [135]. The sensitivity of VOD to AGB was found to decrease as the frequency increases from $L$ to $X$ bands ( $R^{2}$ equals to $0.83,0.71$ and $0.72,0.64$ for $L, C\left(C_{1}\right.$ and $\left.C_{2}\right)$ and $X$ bands) over tropical forests [135]. Good agreement was also found between VOD at L-band from SMOS and SMAP and vegetation height determined using ICESat lidar mission data $[116,144,151,152]$ with $\mathrm{R}=0.87$ between $\mathrm{L}$ band VOD from SMOS-IC and tree heights [144] and $\mathrm{R}^{2}=0.83$ for L band VOD from SMAP MT-DCA [116]. Good results were obtained between the mean VOD at X band from Simultaneous Parameter Retrieval Algorithm (SPRA) AMSR-E (that will be described in the improvements sub-section of the discussion) and canopy height over India $(\mathrm{R}=0.75)$ [153]. VOD at $\mathrm{X}$ band from MASRE-LPRM datasets was found to be strongly correlated to observations of leaf water potential $\left(\Psi_{L}\right)\left(R^{2}\right.$ between 0.6 and 0.8) [154]. 


\subsection{Biomass Monitoring at Regional and Global Scales}

VOD is related to the VWC present in both the photosynthetic (herbaceous, crown and leafy part of trees), especially at higher frequencies, and woody (e.g., woody stems and branches) components, especially at lower frequencies [155]. As VWC is determined by the dry biomass and the moisture content of vegetation (\%), VOD can thus provide information on AGB [134] and the vegetation water status and stress [156]. Very few long-term analyzes of interannual VOD-derived biomass changes were achieved at global scale. Analyzing variations of VOD at Ku band from LPRM between 1988 and 2008, Liu et al. [157] observed that:

1. VOD and rainfall patterns are well correlated over grasslands and shrublands,

2. Increase in mean annual VOD and crop production exhibit similar patterns that were related to rainfall and changes in the agricultural practices,

3. Spatial patterns of VOD decrease can be related to deforestation and exceptional drought events (e.g., the extreme drought of 2005 in Amazonia),

4. VOD declines at regional scales are due to both fires and clear cuttings over boreal forests.

Over drylands, covering $\sim 30 \%$ of the land surfaces, interannual variations in VOD are mostly driven by climate variations (i.e., temperature and rainfall) but are also impacted by anthropogenic effects (e.g., wild fires, grazing pressure) $[59,158]$. For instance, the use of VOD from LPRM over the Tibetan Plateau, allowed to identify a strong decrease in AGB over the grasslands in Mongolia between 1993 and 2012 and the grazing zone of Inner Mongolia Autonomous Region in China between 1993 and 2000 [60,158]. More generally, analyzing LPRM VOD over 1988-2008, woody encroachment was found to be globally widespread to the detriment of herbaceous vegetation in arid drylands, and especially in arid shrublands possibly in response to $\mathrm{CO}_{2}$ fertilization. On the contrary, VOD interannual variations are more influenced by local climate in semi-arid drylands. Fires were identified as an important factor to be considered in the trends analysis over savannas [59]. VOD at X-band from LPRM (AMSR-E) was identified as a good proxy for monitoring live fuel moisture content in the Mediterranean shrublands [159].

VOD is a precious indicator for monitoring the forest loss dynamics. LRPM VOD from SSM/I and AMSR-E were used to quantify the forest loss area in South America between 1990 and 2010, with Brazil being the main contributor over the whole period ( $56 \%$ of the deforestation) is spite of a decrease in the loss observed after 2005 [160]. At smaller scale, a decrease in VOD from ASCAT was observed in the Landes forest (southwest of France) after the Klaus storm which occurred in December 2009 [74].

\subsection{Application for Agriculture}

VOD can be used for the monitoring the phenology of crops. Coarse resolution VOD from radiometers and scatterometers is well suited to monitor major global agro-ecosystems allowing to retrieve cropping patterns $[131,153,161]$. Over several of these major ecosystems (corn and soybean in Iowa, soybean in Argentina, wheat in southwest Australia, mixed crops in Africa, rice in Thailand, rice and wheat in north India), VOD from SMAP MT-DCA was used to monitor the phenological stages of the crops. In Iowa, the peak of VOD was observed at the end of the flowering and the beginning of the maturity stages when biomass and VWC are increasing, and it reached minimum values during the harvest period $[162,163]$ confirming what have been observed for corn using SMOS Level 2 VOD by [164]. VOD at L band from SMOS Level 2 and SMAP MT-DCA was also found to be highly related to crop yield across the USA $[163,165]$. VOD was also related to water amount used by crops for growth and cooling. VOD at L band from SMOS Level 2 and SMAP L2_SM_P_E was found to be proportional to crop water in the US Corn Belt [166].

At higher spatial resolution, WCM was applied to SAR images acquired at various frequencies from $\mathrm{L}$ to $\mathrm{Ku}$ bands to retrieve VOD [167]. VOD was found to be very sensitive to VWC using ERS-2 images acquired at $\mathrm{C}$ band in $\mathrm{VV}$ polarization, whereas the vegetation contribution was related to the two-way attenuation for LAI below 3 and to volume scattering of the vegetation for LAI above 
3, over spring and winter wheat, grassland, and colza, using JERS-1 images acquired at L band in $\mathrm{HH}$ polarization [82]. A high correlation between VOD and VWC was also obtained at X-band using RADARSAT-2 images in $\mathrm{HH}, \mathrm{VV}$, and $\mathrm{HV}$ polarizations over a large variety of crop types (wheat, lentil, peas, fallow, canola and pasture) $\left(\mathrm{R}^{2}=0.89\right)$ [78]. A first VOD mapping was recently achieved over an agricultural area of $50 \mathrm{~km}$ by $50 \mathrm{~km}$ located in Catalonia (Spain) using Sentinel-1 SAR images acquired at $\mathrm{C}$ band in $\mathrm{VH}$ and VV polarizations. VOD was able to detect the decrease in VWC during the senescence with a better correlation in VV than in VH [142].

\subsection{VOD and Carbon Balance}

VOD was found to be highly correlated to AGB. As AGB datasets are generally statics, many studies used spatial correlation of VOD against AGB to assess interannual variations and trends of AGB. L-VOD from the SMOS-IC product was used to quantify annual AGB carbon (AGC) changes over many of the major bioclimatic areas. Decreases in vegetation carbon stocks of 0.05 and 0.02 Pg.year ${ }^{-1}$ were estimated between 2010 and 2016 in the drylands (53\% and $47 \%$ of the study area) and wet areas of Sub-Saharan Africa [150]. The AGC budget was found to be almost in balance in the tropics over 2010-2017 with gross gains and losses of -2.97 and -2.86 Pg.C. $\mathrm{yr}^{-1}$. Large spatio-temporal variations were observed in the tropics during the wet La Niña event of 2011 and the extremely warm and dry and warm 2015-2016 El Niño event. They were found to be mainly controlled by semiarid biomes and highly correlated $(\mathrm{R}=0.86)$ to global anomalies of atmospheric $\mathrm{CO}_{2}$ growth-rate [168]. The recovery after the 2015-2016 El Niño is quite slow. If AGC in tropical dryland areas exhibit similar values in 2017 than before the 2015-2016 El Niño event, carbon stocks of African and American humid forests did not recover yet due to an enhanced mortality during this episode of extreme drought [169]. Combining information from multispectral MODIS reflectance to identify and map forest areas and SMOS-IC L-VOD, a recent study showed that standing AGC stocks increased by $0.11 \pm 0.05 \mathrm{Pg} \mathrm{C} \mathrm{yr}^{-1}$ over 2002-2017 in southern China as a consequence of land use policies.

Analyzing VOD at L, C and X bands from SMOS and AMSR-E processed using LPRM, ASCAT using the approach developed by TU Wien, VOD was found to be correlated to gross primary production (GPP) and Solar-Induced chlorophyll Fluorescence (SIF). Higher R values were obtained with GPP than SIF. These results depend on the frequency, sensor type (active or passive) and land cover [170]. In another study, it was found that GPP can be expressed as a function of VOD through a differential equation [171].

\subsection{VOD and Land Surface Models (LSM)}

Vegetation exerts a strong influence on the water balance of land surfaces through the vertical exchanges with the atmosphere (rainfall and evapotranspiration) and the water uptakes from the root zone, so that the vegetation distribution is strongly controlled by the water availability [172-175]. An early study showed that VOD could be useful to determine the hydraulic properties of soils under a moderate vegetation cover [176]. VOD is still poorly used for validating, calibrating, forcing and assimilating approaches based on LSM. LPRM C-VOD based on SMMR acquisitions was used to filter out SM estimates from the same provider, over areas with dense vegetation (VOD $>0.6$ ) and where the SM retrievals were considered of poor quality, instead of assimilating them in the Catchment Land Surface Model [177]. Coupled approaches between VOD and LSM were envisaged. But the strong RFI contamination of early SMOS Level $2 \mathrm{~T}_{B}$ data prevented the use of VOD at L-band in the PROMET LSM [178]. A recent study, analyzing SM and VOD derived from ASCAT backscattering coefficients over the southwest of France, concluded on the interest of assimilating ASCAT data in the Interaction Sol-Biosphère-Atmosphère (ISBA) LSM in spite of their coarse resolution [74]. In the version 3 of the Global Land Evaporation Amsterdam Model (GLEAM), a set of algorithms estimating root-zone SM and terrestrial evaporation assimilating remotely sensed observations, including VOD from LPRM, was used. VOD is a variable in a non-linear function accounting for the stress factor of the vegetation [179]. This multiplicative stress factor (SF) is defined as: 


$$
\mathrm{SF}=\sqrt{\frac{\mathrm{VOD}}{\mathrm{VOD}_{\max }}}\left(1-\left(\frac{\mathrm{w}_{\mathrm{c}}-\mathrm{w}_{\mathrm{i}}}{\mathrm{w}_{\mathrm{c}}-\mathrm{w}_{\mathrm{wp}}}\right)^{2}\right)
$$

where $\mathrm{VOD}_{\max }$ is the maximum VOD value for each grid point, $\mathrm{w}_{\mathrm{c}}, \mathrm{w}_{\mathrm{i}}$ and $\mathrm{w}_{\mathrm{wp}}$ are the critical $\mathrm{SM}$, the $\mathrm{SM}$ content of the ith layer, the wettest one, and wilting point $\mathrm{SM}$ respectively.

SF ranges between 0 (maximum stress and thus no evaporation) and 1, or the maximum of stress, and consequently, no evapotranspiration (ET), to no stress where ET equals the potential evapotranspiration (ETP).

\section{Discussion}

\subsection{Advantages and Drawbacks of VOD}

Compared to vegetation indices derived from reflectance acquired by sensors operating in the visible and the infra-red domains, VOD is not affected by the presence of clouds and less sensitive to the presence of water in the atmosphere. Thus, the different microwave sensors are likely to provide reliable information related to VWC on both the green and non-green vegetation components [155], at a quasi-daily temporal resolution, at different frequencies and over several decades $[157,180,181]$. VOD gives access to complementary information to NDVI or LAI on the vegetation dynamics for instance [182]. Significant time-lags were observed between LAI and LPRM (AMSR-E) VOD in the Amazon rainforest. It was observed that the growth of the biomass canopy and the phenological activity exhibit maximum time-lags in areas characterized by shorter dry seasons in the west of the basin. This time-lag progressively decreases along a west-to-east longitudinal wetness gradient as the length of the dry season increases indicating an adaptation of forest to water and light availability. In the western part of the Amazon Basin, where the dry period is short, water is allocated to non-photosynthetical vegetation components as a priority when PAR is low (and water availability is maximum), causing an increase in VOD, whereas LAI and PAR exhibit quasi-synchronous temporal variations. In the eastern part of the Amazon Basin, where the duration of the dry season is longer, LAI, and VOD are synchronous with the temporal variations of water availability [183]. In a recent study, a time-lag of three months between LAI and L-VOD from SMOS-IC was determined in the savannah/woodland region of Miombo, in southern Africa. The latter one exhibits a peak at the end of the rainy season and in beginning of the dry season that was attributed to tree growth during this period and was confirmed by in situ observations [184]. X-band VOD is strongly correlated to leaf water potential [154]. As VWC is related to leaf water potential $\left(\Psi_{\mathrm{L}}\right)$, the differences between VOD estimates at mid —-day and midnight was used to derive an isohydricity parameter at ecosystem-scale [185]. As isohydricity is an indicator of the stomatal and xylem flow regulation, which is an important factor in drought-induced reduction of the biomass and plant mortality that cannot be derived from land cover type, VOD is a good candidate for analyzing the spatio-temporal responses of vegetation to water stress. VOD presents saturation for higher biomass values than NDVI, the saturation occurring for lower biomass values as the frequency increases [134]. L-band VOD from SMOS Level 2 was reported to reach saturation for biomass around $350 \mathrm{Mg} \mathrm{ha}^{-1}$ in equatorial forests of South America and Africa [186]. In spite of differences in spatio-temporal patterns between VODs derived from different sensor types, and at various frequencies and, for different inversion approaches (see for instance Figure 4), very few inter-comparison studies have been achieved yet. A first study based on one year (2003) of AMSR-E $\mathrm{T}_{\mathrm{B}}$ acquired at $\mathrm{C}-(6.925 \mathrm{GHz}), \mathrm{X}-(10.65 \mathrm{GHz})$, and $\mathrm{K}-(18.7 \mathrm{GHz})$ bands showed a greater sensitivity of microwave data acquired at higher frequencies to the photosynthetically active component of vegetation (crown and leaves), whereas, $T_{B}$ acquired at lower frequencies are more sensitive to the woody component of the vegetation [155]. These results were confirmed when comparing L- (SMAP MT-DCA data), X- and C- (AMSR-2 LPRM version 5 data) bands VOD to AGB over tropical forests [135]. Comparisons between different L-band VOD from SMOS (i.e., SMOS Level 2, SMOS Level 3 and SMOS-IC v105) and three different AGB datasets, as well as three height NDVI and EVI also exhibited 
very good agreement between the different parameters. Among the L-VOD products, SMOS-IC v105 obtained the higher correlations and lower dispersion against all the evaluated VOD datasets [144].
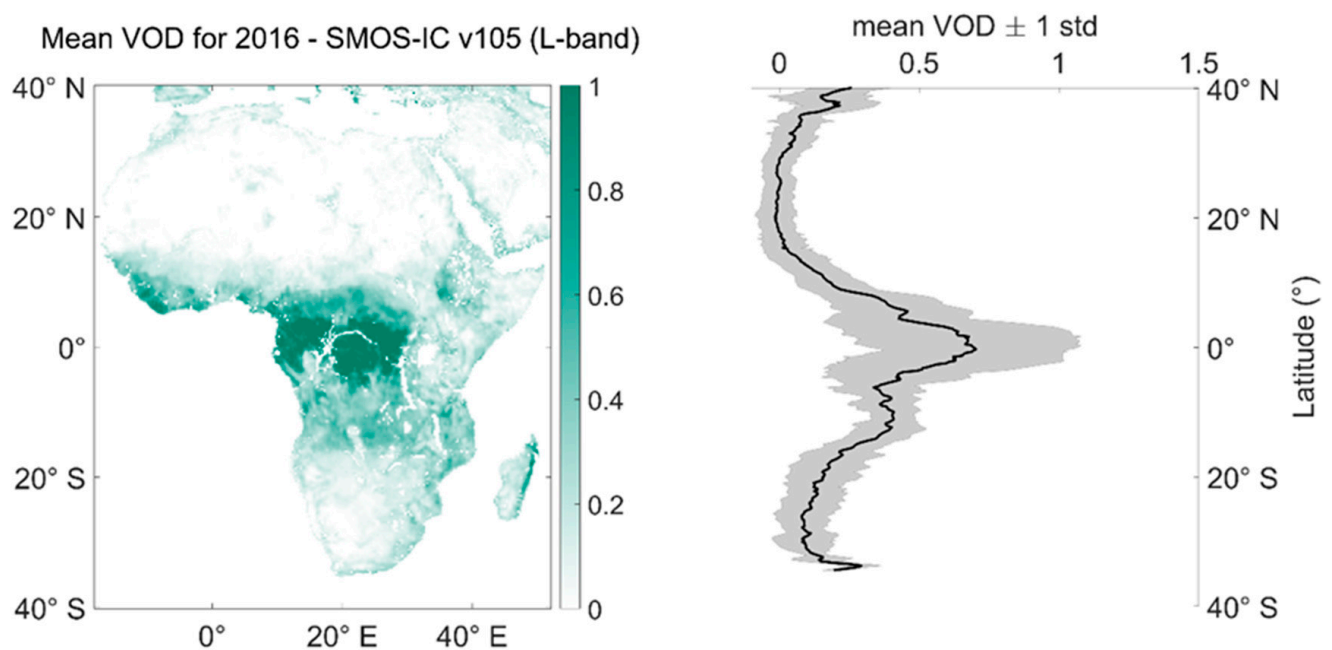

(a)
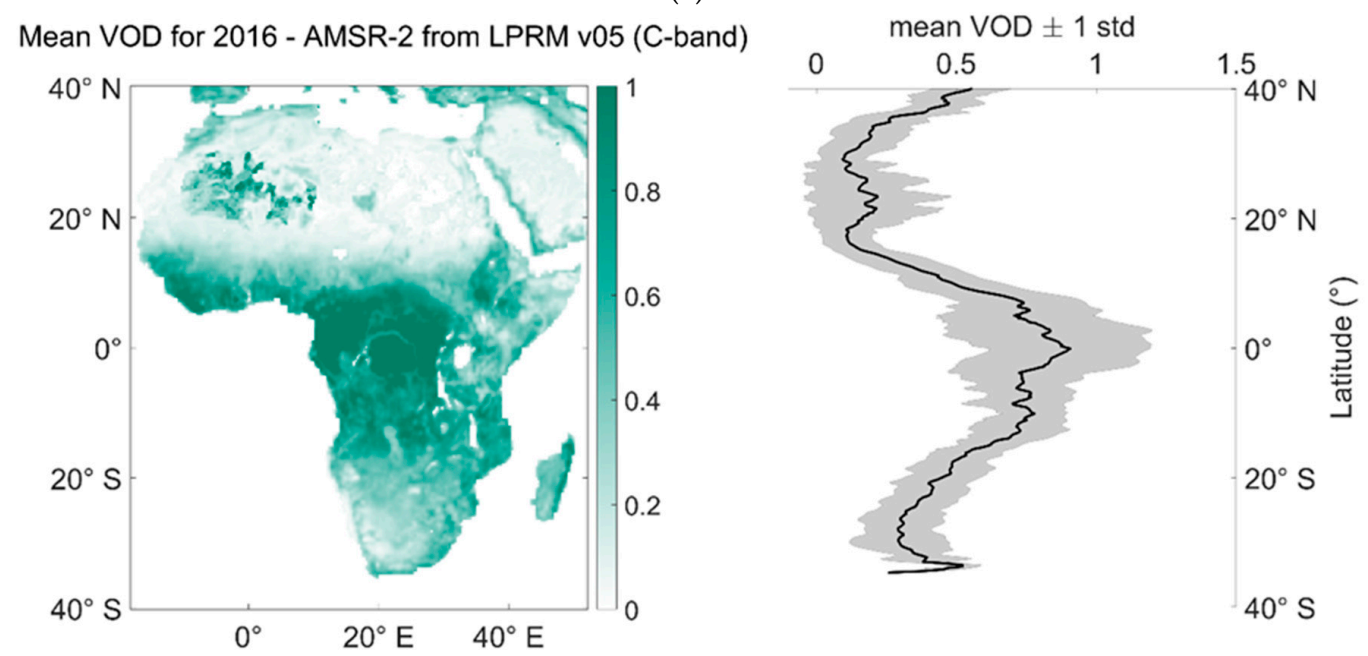

(b)
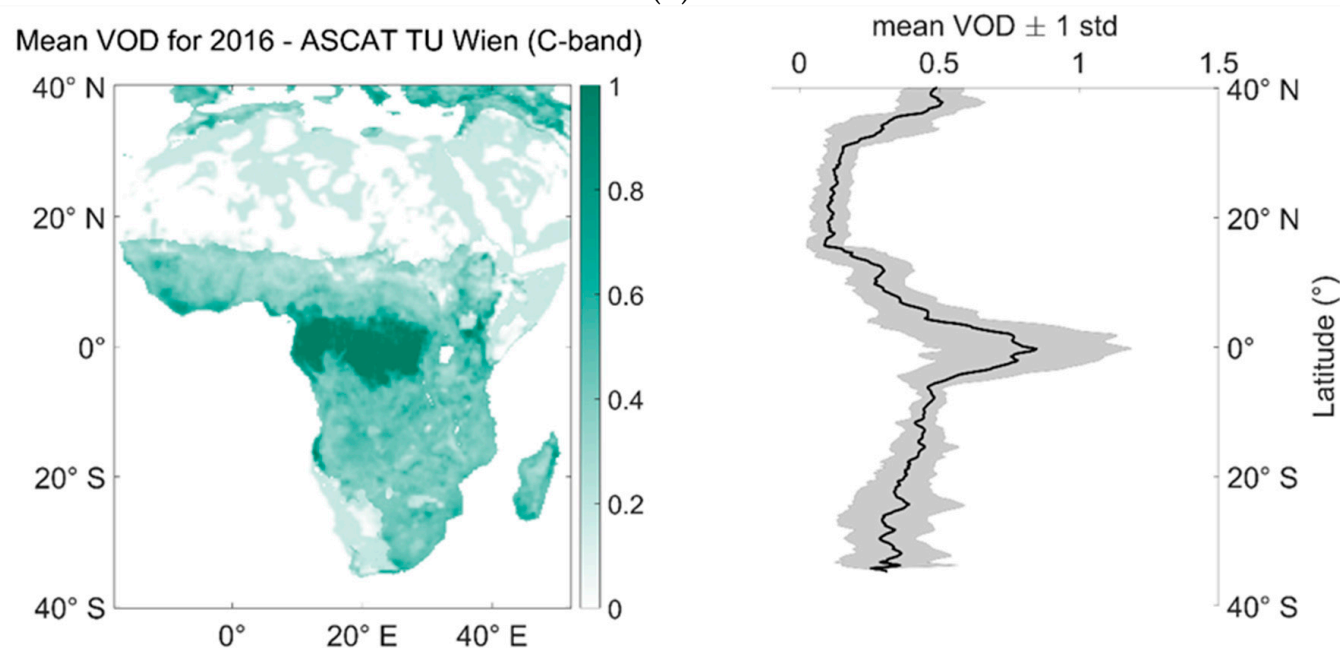

(c)

Figure 4. (a) Average Vegetation Optical Depth (VOD) over Africa from SMOS-IC v105 for 2016 (left) and corresponding zonal average (right); (b) Same for AMSR-2 from Land Parameter Retrieval Model (LPRM) v05; (c) Same for Advanced Scatterometer (ASCAT) from TU Wien. 
The major drawbacks of the current VOD products from radiometers and scatterometers are their sensitivity to RFI, the loss of accuracy in presence of water bodies in the sensor footprint, and their coarse spatial resolutions. Concerning the important issue of the RFI, preprocessing approaches are increasingly improving to filter out the data impacted by these perturbations. For example, in the version 2 of the SMOS-IC data, available at [103], a special attention was devoted to the prefiltering step allowing to improve the quality of the VOD retrievals compared to v105 [187]. To tackle with the loss of accuracy of VOD in presence of open water, the solution currently used is to filter out pixels containing a percentage of water higher than a threshold. Corrections are difficult as they would require very accurate and Near Real Time (NRT) maps of the water bodies. But inundation fractions are retrieved from SSM/I $[188,189]$ and SMOS $[190,191]$ for instance. A possible solution would be to retrieve simultaneously the surface water fraction, SM and VOD combining information from several frequencies, and/or polarizations. Improvement in the VOD spatial resolution already started with the availability of Level 1c SMAP T $\mathrm{B}$ at a spatial resolution of $9 \mathrm{~km}$ instead of $36 \mathrm{~km}$ owing to the use of a Backus-Gilbert approach [110]. But no similar product has been yet developed for SMOS. A promising technique, based on the combination of successive acquisitions and the application of constraints based on the expected climatology-based range of variations of the inverted parameters, and the Sobolev-norm regularization, was recently applied on $\mathrm{T}_{\mathrm{B}}$ from SMAP over the Contiguous United States (CONUS). This approach, denominated "combined constrained multi-channel algorithm" (C-CMCA), allowed simultaneous retrievals of SM and VOD at spatial resolutions from 1 to $5 \mathrm{~km}$ decreasing the RMSE values on VOD estimates by $81 \%$ and $7 \%$ respectively compared with non-constrained and single source techniques, respectively [192]. Other techniques were also implemented to other space-borne observations. Using pan-sharpening technique on $\mathrm{T}_{\mathrm{B}}$ acquired by AMSR-E at Ka- (higher resolution) and C- (lower resolution) band, high resolution SM and VOD were obtained from LPRM at the spatial resolution of $10 \mathrm{~km}$ instead of $25 \mathrm{~km}$ [193].

\subsection{Decoupling the Effects of Biomass and Vegetation Water Status on VOD}

As discussed above, VOD has generally been found to be linearly related to the vegetation water content (VWC, $\left.\mathrm{kg} \cdot \mathrm{m}^{-2}\right)$.

VWC can be related to both biomass and to the vegetation water status; the latter can be parameterized by the vegetation moisture content $(\mathrm{Mg}(\%)$, the ratio between wet biomass and total (dry + wet) biomass) [194], the relative water content (RWC), the live fuel moisture content (LFMC) or the leaf or xylem water potential [41]. Considering the parameterization based on $\mathrm{Mg}$, VWC can be written as:

$$
\mathrm{VWC}=\mathrm{B}_{\mathrm{s}} \frac{1-\mathrm{M}_{\mathrm{g}}}{\mathrm{M}_{\mathrm{g}}}
$$

with:

$$
\mathrm{M}_{\mathrm{g}}=\frac{\mathrm{VWC}}{\mathrm{VWC}+\mathrm{B}_{\mathrm{s}}}
$$

where $B_{\mathrm{s}}$ represent vegetation (dry) biomass $\left(\mathrm{kg} \cdot \mathrm{m}^{-2}\right)$.

Decoupling the effect of $B_{S}$ and $M_{g}$ on VOD, as a proxy of VWC, is not straightforward as both $B_{S}$ and $\mathrm{M}_{\mathrm{g}}$ may present simultaneous time variations.

However, specific vegetation properties can be used in this decoupling to retrieve biomass:

1. Mg present strong daily and seasonal changes in $\mathrm{VWC}$, but its average value is relatively stable at an annual scale. At least, it is very likely the yearly average of $\mathrm{Mg}$ does not present long term increasing or decreasing trends ("long term" corresponding here to time periods $>5$ to 10 years); long term decreasing trends in the vegetation moisture content would lead to mortality; similarly, long term increasing trends in the vegetation moisture content have never been reported in the literature.

2. During the rainfall period, in regions/continents where clear wet seasons can be distinguished, the root zone soil volume is recharged with water and $\mathrm{Mg}$ gets back its maximum value $\left(\mathrm{M}_{\text {gmax }}\right)$. 
Over a given pixel, it is very likely the value of $\mathrm{M}_{\mathrm{gmax}}$, which mainly depends on the vegetation type is relatively constant from year to year. This assumption can be confirmed by results in intact forest regions and non-affected by severe drought/mortality events, showing that VOD present a clear annual cycle with minimum values during the dry season and that it recovers each year to the same value during the wet season $[150,169]$.

Relying on 1 and 2, it can be stated that:

- Considering that the yearly average value of $\mathrm{M}_{\mathrm{g}}$ does not present long term trends, long term changes in yearly average of VOD can be directly related to biomass changes,

- Considering $\mathrm{M}_{\mathrm{g}}$ is relatively constant from year to year during wet periods $\left(\mathrm{M}_{\mathrm{g}} \sim \mathrm{M}_{\mathrm{gmax}}\right)$, the retrieved VOD during the wet period $\left(\mathrm{VOD}_{\max }\right)$ is proportional to biomass:

$$
\operatorname{VOD}_{\max } \sim \mathrm{B}_{\mathrm{s}} \frac{1-\mathrm{M}_{\mathrm{gmax}}}{\mathrm{M}_{\text {gmax }}}
$$

Note that changes in biomass over short term periods are not accessible from the above approaches.

\subsection{New Opportunities for VOD from Current and Future EOS Missions}

Continuity of VOD monitoring seems ensured for the coming years as numerous recent passive (SMAP, AMSR2, ... ) and active (ASCAT, SCAT, ... ) microwave sensors are still in operation; One of the top priority of the European Copernicus Expansion program is the Copernicus Imaging Microwave Radiometer (CIMR) mission, a radiometer operating, for the very first time, at $\mathrm{L}(1.4 \mathrm{GHz}), \mathrm{C}(6.9 \mathrm{GHz})$, $\mathrm{X}(10.65 \mathrm{GHz}), \mathrm{K}(18.7 \mathrm{GHz})$, and $\mathrm{Ka}(36.5 \mathrm{GHz})$ frequency bands with the corresponding spatial resolutions of 55, 15, 15, 5 and $5 \mathrm{~km}$ respectively [38]. Although, the CIMR main mission objective will be, after 2025, to monitor the ocean surface in the Arctic environment to provide accurate estimates of sea surface temperature and salinity (SST and SSS), ocean wind speed, and sea ice concentration (SIC), it will provide global measurement of $T_{B}$ from $L$ to Ka bands, on a sun synchronous orbit, that will give the possibility retrieve VOD at low and high frequencies to jointly analyze AGB and VWC temporal changes.

The recent launch of the Surface Waves Investigation and Monitoring (SWIM) low incidence $\left(0-10^{\circ}\right)$ scatterometer [195] offers a unique opportunity to assess the potential of backscattering coefficients acquired at low incidences for simultaneous inversion of SSM and VOD through the WCM and their potential to desegregate VOD derived from lower resolution sensors. The data from the China France Oceanography Satellite (CFOSAT), launched in October 2018, with its payload composed of a classical scatterometer (SCAT) acquiring data at incidences ranging from $26^{\circ}$ to $46^{\circ}$, and SWIM, both operating at Ku-band (13.256 and $13.525 \mathrm{GHz}$ respectively) [196] are the good candidates for analyzing a possible complementarity between low and medium incidence angles. A first result of VOD retrieval from SWIM backscattering exhibits a good correlation with MODIS-based NDVI in the south of the semi-arid region of Sahel in Africa (Figure 5). This could be extended to radar altimetry missions which simultaneously acquire backscattering coefficients at one or two frequencies, generally at $\mathrm{C}$ $(\sim 5.3 \mathrm{GHz})$ and $\mathrm{Ku}(\sim 13.5 \mathrm{GHz})$, and brightness temperatures at two or three frequencies at $\mathrm{K}(\sim 18.5$ and between 22 and $24 \mathrm{GHz}$ ) and $\mathrm{Ka}$ (between 34 and $37 \mathrm{GHz}$ ) at nadir. As altimetry records start in 1991 for high accuracy missions, this data source would be able to provide long term estimates of VOD and/or could be used for disaggregating lower resolution VOD products, especially at high latitudes where radar altimetry tracks coverage is dense. Early results showed quite stable backscattering over equatorial forests [197-200] and a strong sensitivity to SM over semi-arid areas [201,202]. 


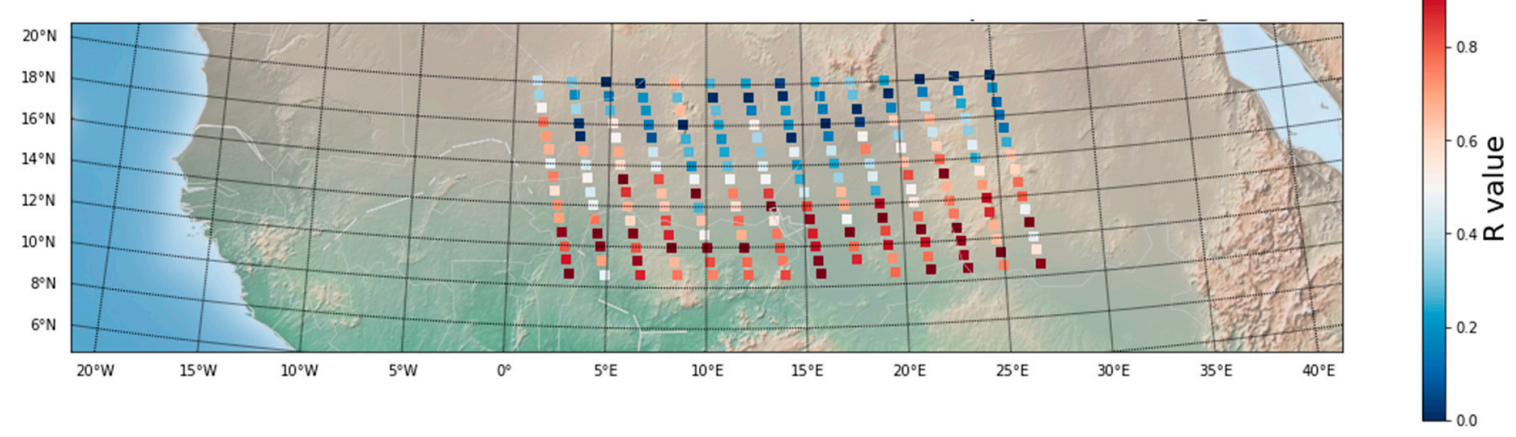

Figure 5. Correlation between VOD retrievals from Surface Waves Investigation and Monitoring (SWIM) backscattering coefficients acquired along the ascending tracks and NDVI from MODIS over the central part of the semi-arid region of Sahel in Africa.

The Copernicus Sentinel-1 mission, which has been providing high resolution ( 10 $\mathrm{m})$ SAR images at C-band since 2013, sampling the Earth surface with a temporal resolution from 6 to 12 days at VV and VH polarizations in Interferometric Wide-swath mode (IW) [203], already demonstrated a strong potential to estimate VOD either directly [77] or using the complementarity with a low resolution sensor as SMAP [204]. For denser vegetation cover, the succession of L-band SAR put into orbit (JERS-1, PALSAR-1 and 2) or under development (PALSAR-3) by JAXA offers the opportunity to monitor long term changes in biomass in tropical forest. The future ESA Biomass, to be launched in 2022, providing SAR images at 50 of spatial resolution, will be the first to operate in P-band $(0.435 \mathrm{GHz})$. Less prone to saturation at high biomass values, P-band VOD would be likely to provide insights on AGB in dense forests.

L-band Global Navigation Satellite Systems (GNSS) signals reflected by the Earth surface and processed either analyzing the signal to noise ratio (SNR) measured by a single antenna coupled to a geodetic receiver or computing the delay-Doppler maps (DDM) acquired by a two-antenna sensors, are opportunistically used to characterize sea and land surface properties [205]. Retrieved parameters from processing GNSS reflectometry (GNSS-R) data acquired from in-situ, airborne or spaceborne were found to be correlated with AGB and vegetation phenology [206-210]. VOD estimates using GNSS-R still need to be evaluated.

\section{Conclusions}

VOD retrieved from both passive and active microwave remotely sensed observations has been providing a long-term record of the vegetation dynamics over land surfaces since 1978. It has been shown, in many studies that VOD offers complementary information to the commonly used vegetation indices derived from multi-spectral images as NDVI, LAI or fPAR and presents several advantages compared to these indices. It is much less affected by the presence of water in the atmosphere and is a proxy of the vegetation water content/ biomass of the whole the canopy even layer in the tropical forests at L-band. The various frequencies available and the different sensing modes of the space-borne sensors give access to a wide range of vegetation variables as essential as the water status of the top-canopy layer at higher frequencies and the biomass at lower frequencies. Yet, the synergy between observations acquired for different frequencies and sensing modes (active and passive) need to be explored further to better understand the functioning of the vegetation in a context of both climate change and increased anthropogenic pressure on the vegetation ecosystems. The launch of satellite missions such as CIMR and Biomass in the years to come will ensure the continuity in the monitoring of land surfaces using passive microwave sensors and offer new information based on the use of multi-frequency bands (for CIMR) of low frequency P-band (for Biomass), respectively. 
Author Contributions: Conceptualization, F.F. and J.-P.W.; writing—original draft preparation, F.F.; writing—review and editing, all co-authors; figures, F.F., X.L. (Xiaojun Li) and X.L. (Xiangzhuo Liu) provided data for Figure 4; Z.A.L. provided Figure 5; funding acquisition, F.F. and J.-P.W. All authors have read and agreed to the published version of the manuscript.

Funding: This research was funded by the CNES TOSCA grant Continental Surface Characteristics from Multi-Incidence Radar at Ku-band (CASCHMIR).

Acknowledgments: The authors want to thank VisoTerra for funding B.Y. PhD grant through the ANRT CIFRE doctoral program and China Scholarship Council (CSC) for funding X.L. (Xiaojun Li), X.L. (Xiangzhuo Liu) and M.W. PhD grants. We thank two anonymous Reviewers who helped improve the manuscript.

Conflicts of Interest: The authors declare no conflict of interest.

\section{References}

1. Richardson, A.D.; Keenan, T.F.; Migliavacca, M.; Ryu, Y.; Sonnentag, O.; Toomey, M. Climate change, phenology, and phenological control of vegetation feedbacks to the climate system. Agric. For. Meteorol. 2013, 169, 156-173. [CrossRef]

2. Kelly, A.E.; Goulden, M.L. Rapid shifts in plant distribution with recent climate change. Proc. Natl. Acad. Sci. USA 2008, 105, 11823-11826. [CrossRef] [PubMed]

3. Buitenwerf, R.; Rose, L.; Higgins, S.I. Three decades of multi-dimensional change in global leaf phenology. Nat. Clim. Chang. 2015, 5, 364-368. [CrossRef]

4. Ma, X.; Huete, A.; Moran, S.; Ponce-Campos, G.; Eamus, D. Abrupt shifts in phenology and vegetation productivity under climate extremes. J. Geophys. Res. Biogeosci. 2015, 120, 2036-2052. [CrossRef]

5. Zhang, K.; Kimball, J.S.; Hogg, E.H.; Zhao, M.; Oechel, W.C.; Cassano, J.J.; Running, S.W. Satellite-based model detection of recent climate-driven changes in northern high-latitude vegetation productivity. J. Geophys. Res. Biogeosci. 2008, 113. [CrossRef]

6. Guay, K.C.; Beck, P.S.A.; Berner, L.T.; Goetz, S.J.; Baccini, A.; Buermann, W. Vegetation productivity patterns at high northern latitudes: A multi-sensor satellite data assessment. Glob. Chang. Biol. 2014, 20, 3147-3158. [CrossRef]

7. Walther, G.R. Plants in a warmer world. Perspect. Plant Ecol. Evol. Syst. 2004, 6, 169-185. [CrossRef]

8. Gonzalez, P.; Neilson, R.P.; Lenihan, J.M.; Drapek, R.J. Global patterns in the vulnerability of ecosystems to vegetation shifts due to climate change. Glob. Ecol. Biogeogr. 2010, 19, 755-768. [CrossRef]

9. Mueller, R.C.; Scudder, C.M.; Porter, M.E.; Talbot Trotter, R.; Gehring, C.A.; Whitham, T.G. Differential tree mortality in response to severe drought: Evidence for long-term vegetation shifts. J. Ecol. 2005, 93, 1085-1093. [CrossRef]

10. Higgins, S.I.; Scheiter, S. Atmospheric CO 2 forces abrupt vegetation shifts locally, but not globally. Nature 2012, 488, 209-212. [CrossRef]

11. Jia, G.J.; Epstein, H.E.; Walker, D.A. Vegetation greening in the canadian arctic related to decadal warming. J. Environ. Monit. 2009, 11, 2231-2238. [CrossRef] [PubMed]

12. Piao, S.; Tan, J.; Chen, A.; Fu, Y.H.; Ciais, P.; Liu, Q.; Janssens, I.A.; Vicca, S.; Zeng, Z.; Jeong, S.J.; et al. Leaf onset in the northern hemisphere triggered by daytime temperature. Nat. Commun. 2015, 6, 1-8. [CrossRef] [PubMed]

13. Yu, F.; Price, K.P.; Ellis, J.; Shi, P. Response of seasonal vegetation development to climatic variations in eastern central Asia. Remote Sens. Environ. 2003, 87, 42-54. [CrossRef]

14. Phillips, O.L.; Aragão, L.E.O.C.; Lewis, S.L.; Fisher, J.B.; Lloyd, J.; López-González, G.; Malhi, Y.; Monteagudo, A.; Peacock, J.; Quesada, C.A.; et al. Drought sensitivity of the amazon rainforest. Science 2009, 323, 1344-1347. [CrossRef]

15. Lewis, S.L.; Brando, P.M.; Phillips, O.L.; Van Der Heijden, G.M.F.; Nepstad, D. The 2010 Amazon drought. Science 2011, 331, 554. [CrossRef] [PubMed]

16. Pearson, R.G.; Phillips, S.J.; Loranty, M.M.; Beck, P.S.A.; Damoulas, T.; Knight, S.J.; Goetz, S.J. Shifts in Arctic vegetation and associated feedbacks under climate change. Nat. Clim. Chang. 2013, 3, 673-677. [CrossRef]

17. Bachelet, D.; Neilson, R.P.; Lenihan, J.M.; Drapek, R.J. Climate change effects on vegetation distribution and carbon budget in the United States. Ecosystems 2001, 4, 164-185. [CrossRef]

18. Lenihan, J.M.; Bachelet, D.; Neilson, R.P.; Drapek, R. Response of vegetation distribution, ecosystem productivity, and fire to climate change scenarios for California. Clim. Chang. 2007, 87, 215-230. [CrossRef]

19. Tucker, C.J. Red and photographic infrared linear combinations for monitoring vegetation. Remote Sens. Environ. 1979, 8, 127-150. [CrossRef] 
20. Huete, A.; Justice, C.; Liu, H. Development of vegetation and soil indices for MODIS-EOS. Remote Sens. Environ. 1994, 49, 224-234. [CrossRef]

21. Zhou, L.; Tucker, C.J.; Kaufmann, R.K.; Slayback, D.; Shabanov, N.V.; Myneni, R.B. Variations in northern vegetation activity inferred from satellite data of vegetation index during 1981 to 1999. J. Geophys. Res. Atmos. 2001, 106, 20069-20083. [CrossRef]

22. Kawabata, A.; Ichii, K.; Yamaguchi, Y. Global monitoring of interannual changes in vegetation activities using NDVI and its relationships to temperature and precipitation. Int. J. Remote Sens. 2001, 22, 1377-1382. [CrossRef]

23. Zhang, X.; Friedl, M.A.; Schaaf, C.B.; Strahler, A.H.; Hodges, J.C.F.; Gao, F.; Reed, B.C.; Huete, A. Monitoring vegetation phenology using MODIS. Remote Sens. Environ. 2003, 84, 471-475. [CrossRef]

24. Beck, P.S.A.; Atzberger, C.; Høgda, K.A.; Johansen, B.; Skidmore, A.K. Improved monitoring of vegetation dynamics at very high latitudes: A new method using MODIS NDVI. Remote Sens. Environ. 2006, 100, 321-334. [CrossRef]

25. Fuller, D.O. Trends in ndvi time series and their relation to rangeland and crop production in senegal, 1987-1993. Int. J. Remote Sens. 1998, 19, 2013-2018. [CrossRef]

26. Wang, J.; Rich, P.M.; Price, K.P.; Kettle, W.D. Relations between NDVI and tree productivity in the central Great Plains. Int. J. Remote Sens. 2004, 25, 3127-3138. [CrossRef]

27. Wang, J.; Price, K.P.; Rich, P.M. Spatial patterns of NDVI in response to precipitation and temperature in the central Great Plains. Int. J. Remote Sens. 2001, 22, 3827-3844. [CrossRef]

28. Carlson, T.N.; Ripley, D.A. On the relation between NDVI, fractional vegetation cover, and leaf area index. Remote Sens. Environ. 1997, 62, 241-252. [CrossRef]

29. Wang, Q.; Adiku, S.; Tenhunen, J.; Granier, A. On the relationship of NDVI with leaf area index in a deciduous forest site. Remote Sens. Environ. 2005, 94, 244-255. [CrossRef]

30. Gamon, J.A.; Field, C.B.; Goulden, M.L.; Griffin, K.L.; Hartley, A.E.; Joel, G.; Penuelas, J.; Valentini, R. Relationships between NDVI, canopy structure, and photosynthesis in three Californian vegetation types. Ecol. Appl. 1995, 5, 28-41. [CrossRef]

31. Carlson, T.N.; Gillies, R.R.; Perry, E.M. A method to make use of thermal infrared temperature and NDVI measurements to infer surface soil water content and fractional vegetation cover. Remote Sens. Rev. 1994, 9 , 161-173. [CrossRef]

32. Lu, H.; Raupach, M.R.; McVicar, T.R.; Barrett, D.J. Decomposition of vegetation cover into woody and herbaceous components using AVHRR NDVI time series. Remote Sens. Environ. 2003, 86, 1-18. [CrossRef]

33. Los, S.O.; Collatz, G.J.; Sellers, P.J.; Malmström, C.M.; Pollack, N.H.; DeFries, R.S.; Bounoua, L.; Parris, M.T.; Tucker, C.J.; Dazlich, D.A. A global 9-yr biophysical land surface dataset from NOAA AVHRR data. J. Hydrometeorol. 2000, 1, 183-199. [CrossRef]

34. Myneni, R.B.; Hoffman, S.; Knyazikhin, Y.; Privette, J.L.; Glassy, J.; Tian, Y.; Wang, Y.; Song, X.; Zhang, Y.; Smith, G.R.; et al. Global products of vegetation leaf area and fraction absorbed PAR from year one of MODIS data. Remote Sens. Environ. 2002, 83, 214-231. [CrossRef]

35. Stöckli, R.; Vidale, P.L. European plant phenology and climate as seen in a 20-year AVHRR land-surface parameter dataset. Int. J. Remote Sens. 2004, 25, 3303-3330. [CrossRef]

36. Turner, D.P.; Ritts, W.D.; Cohen, W.B.; Gower, S.T.; Running, S.W.; Zhao, M.; Costa, M.H.; Kirschbaum, A.A.; Ham, J.M.; Saleska, S.R.; et al. Evaluation of MODIS NPP and GPP products across multiple biomes. Remote Sens. Environ. 2006, 102, 282-292. [CrossRef]

37. Yang, W.; Huang, D.; Tan, B.; Stroeve, J.C.; Shabanov, N.V.; Knyazikhin, Y.; Nemani, R.R.; Myneni, R.B. Analysis of leaf area index and fraction of PAR absorbed by vegetation products from the terra MODIS sensor: 2000-2005. IEEE Trans. Geosci. Remote Sens. 2006, 44, 1829-1841. [CrossRef]

38. Kilic, L.; Prigent, C.; Aires, F.; Boutin, J.; Heygster, G.; Tonboe, R.T.; Roquet, H.; Jimenez, C.; Donlon, C. Expected Performances of the Copernicus Imaging Microwave Radiometer (CIMR) for an All-Weather and High Spatial Resolution Estimation of Ocean and Sea Ice Parameters. J. Geophys. Res. Ocean. 2018, 123, 7564-7580. [CrossRef]

39. Desnos, Y.L.; Buck, C.; Guijarro, J.; Suchail, J.L.; Torres, R.; Attema, E. ASAR—Envisat's Advanced Synthetic Aperture Radar-Building on ERS achievements towards future earth watch missions. ESA Bull. 2000, 102, 91-100. 
40. Rosenqvist, A.; Shimada, M.; Suzuki, S.; Ohgushi, F.; Tadono, T.; Watanabe, M.; Tsuzuku, K.; Watanabe, T.; Kamijo, S.; Aoki, E. Operational performance of the ALOS global systematic acquisition strategy and observation plans for ALOS-2 PALSAR-2. Remote Sens. Environ. 2014, 155, 3-12. [CrossRef]

41. Konings, A.G.; Rao, K.; Steele-Dunne, S.C. Macro to micro: Microwave remote sensing of plant water content for physiology and ecology. New Phytol. 2019, 223, 1166-1172. [CrossRef] [PubMed]

42. Ulaby, F.; Long, D.; Blackwell, W.; Elachi, C.; Fung, A.; Ruf, C.; Sarabandi, K.; Zyl, J.; Zebker, H. Microwave Radar and Radiometric Remote Sensing; Artech House: Norwood, MA, USA, 2014; ISBN 978-0-472-11935-6.

43. Attema, E.P.W.; Ulaby, F.T. Vegetation modeled as a water cloud. Radio Sci. 1978, 13, 357-364. [CrossRef]

44. Schmugge, T.J.; Jackson, T.J. Dielectric Model of the Vegetation Effects on the Microwave Emission from Soils. IEEE Trans. Geosci. Remote Sens. 1992, 30, 757-760. [CrossRef]

45. Ulaby, F.T.; Moore, R.K.; Fung, A.K. Microwave Remote Sensing: Active and Passive. Volume III: From Theory to Applications; Artech House: Norwood, MA, USA, 1986.

46. Choudhury, B.J.; Tucker, C.J.; Golus, R.E.; Newcomb, W.W. Monitoring vegetation using nimbus-7 scanning multichannel microwave radiometer's data. Int. J. Remote Sens. 1987, 8, 533-538. [CrossRef]

47. Wigneron, J.P.; Guyon, D.; Calvet, J.C.; Courrier, G.; Bruguier, N. Monitoring coniferous forest characteristics using a multifrequency (5-90 GHz) microwave radiometer. Remote Sens. Environ. 1997, 60, 299-310. [CrossRef]

48. Saatchi, S.S.; Van Zyl, J.J.; Asrar, G. Estimation of canopy water content in Konza Prairie grasslands using synthetic aperture radar measurements during FIFE. J. Geophys. Res. 1995, 100, 25481-25496. [CrossRef]

49. Saatchi, S.S.; Moghaddam, M. Estimation of crown and stem water content and biomass of boreal forest using polarimetric SAR imagery. IEEE Trans. Geosci. Remote Sens. 2000, 38, 697-709. [CrossRef]

50. Hajj, M.; El Baghdadi, N.; Zribi, M.; Bazzi, H. Synergic use of Sentinel-1 and Sentinel-2 images for operational soil moisture mapping at high spatial resolution over agricultural areas. Remote Sens. 2017, 9, 1292. [CrossRef]

51. Wigneron, J.-P.; Kerr, Y.; Chanzy, A.; Jin, Y.-Q. Inversion of surface parameters from passive microwave measurements over a soybean field. Remote Sens. Environ. 1993, 46, 61-72. [CrossRef]

52. Choudhury, B.J.; Wang, J.R.; Hsu, A.Y.; Chien, Y.L. Simulated and observed 37 GHZ emission over Africa. Int. J. Remote Sens. 1990, 11, 1837-1868. [CrossRef]

53. Rauste, Y.; Häme, T.; Pulliainen, J.; Heiska, K.; Hallikainen, M. Radar-based forest biomass estimation. Int. J. Remote Sens. 1994, 15, 2797-2808. [CrossRef]

54. Rignot, E.; Williams, C.; Viereck, L. Radar Estimates of Aboveground Biomass in Boreal Forests of Interior Alaska. IEEE Trans. Geosci. Remote Sens. 1994, 32, 1117-1124. [CrossRef]

55. Dobson, M.C.; Ulaby, F.T.; Le Toan, T.; Beaudoin, A.; Kasischke, E.S.; Christensen, N. Dependence of Radar Backscatter on Coniferous Forest Biomass. IEEE Trans. Geosci. Remote Sens. 1992, 30, 412-415. [CrossRef]

56. Baghdadi, N.; Le Maire, G.; Bailly, J.S.; Osé, K.; Nouvellon, Y.; Zribi, M.; Lemos, C.; Hakamada, R. Evaluation of ALOS/PALSAR L-Band Data for the Estimation of Eucalyptus Plantations Aboveground Biomass in Brazil. IEEE J. Sel. Top. Appl. Earth Obs. Remote Sens. 2015, 8, 3802-3811. [CrossRef]

57. Wigneron, J.-P.; Kerr, Y. Passive low frequency microwaves: Principles, radiative transfer, physics of measurements. In Microwave Remote Sensing of Land Surface; Elsevier: Amsterdam, The Netherlands, 2016; pp. 219-283.

58. Frison, P.-L.L.; Jarlan, L.; Mougin, E. Using satellite scatterometers to monitor continental surfaces. In Land Surface Remote Sensing in Continental Hydrology; Elsevier: Amsterdam, The Netherlands, 2016; pp. 79-113. ISBN 9780081011812.

59. Andela, N.; Liu, Y.Y.M.; Van Dijk, A.I.J.; De Jeu, R.A.M.; McVicar, T.R. Global changes in dryland vegetation dynamics (1988-2008) assessed by satellite remote sensing: Comparing a new passive microwave vegetation density record with reflective greenness data. Biogeosciences 2013, 10, 6657-6676. [CrossRef]

60. Zhou, X.; Yamaguchi, Y.; Arjasakusuma, S. Distinguishing the vegetation dynamics induced by anthropogenic factors using vegetation optical depth and AVHRR NDVI: A cross-border study on the Mongolian Plateau. Sci. Total Environ. 2018, 616-617, 730-743. [CrossRef]

61. Njoku, E.G.; Entekhabi, D. Passive microwave remote sensing of soil moisture. J. Hydrol. 1996, 184, 101-129. [CrossRef]

62. Ulaby, F.T.; Dobson, M.C. Handbook of Radar Scattering Statistics for Terrain; Artech House: Norwood, MA, USA, 1989; Volume 1, ISBN 0890063362.

63. Mo, T.; Choudhury, B.J.; Schmugge, T.J.; Wang, J.R.; Jackson, T.J. A model for microwave emission from vegetation-covered fields. J. Geophys. Res. 1982, 87, 11229-11237. [CrossRef] 
64. Ulaby, F.T.; Aslam, A.; Dobson, M.C. Effects of Vegetation Cover on the Radar Sensitivity to Soil Moisture. IEEE Trans. Geosci. Remote Sens. 1982, GE-20, 476-481. [CrossRef]

65. Feldman, A.F.; Akbar, R.; Entekhabi, D. Characterization of higher-order scattering from vegetation with SMAP measurements. Remote Sens. Environ. 2018, 219, 324-338. [CrossRef]

66. Wigneron, J.P.; Jackson, T.J.; O’Neill, P.; De Lannoy, G.; de Rosnay, P.; Walker, J.P.; Ferrazzoli, P.; Mironov, V.; Bircher, S.; Grant, J.P.; et al. Modelling the passive microwave signature from land surfaces: A review of recent results and application to the L-band SMOS \& SMAP soil moisture retrieval algorithms. Remote Sens. Environ. 2017, 192, 238-262.

67. Della Vecchia, A.; Saleh, K.; Ferrazzoli, P.; Guerriero, L.; Wigneron, J.P. Simulating L-Band Emission of Coniferous Forests Using a Discrete Model and a Detailed Geometrical Representation. IEEE Geosci. Remote Sens. Lett. 2006, 3, 364-368. [CrossRef]

68. Della Vecchia, A.; Ferrazzoli, P.; Wigneron, J.P.; Grant, J.P. Modeling forest emissivity at L-band and a comparison with multitemporal measurements. IEEE Geosci. Remote Sens. Lett. 2007, 4, 508-512. [CrossRef]

69. Ferrazzoli, P.; Guerriero, L. Passive microwave remote sensing of forests: A model investigation. IEEE Trans. Geosci. Remote Sens. 1996, 34, 433-443. [CrossRef]

70. Ferrazzoli, P.; Guerriero, L.; Wigneron, J.P. Simulating L-band emission of forests in view of future satellite applications. IEEE Trans. Geosci. Remote Sens. 2002, 40, 2700-2708. [CrossRef]

71. Schwank, M.; Naderpour, R.; Mätzler, C. "Tau-Omega"- and Two-Stream Emission Models Used for Passive L-Band Retrievals: Application to Close-Range Measurements over a Forest. Remote Sens. 2018, 10, 1868. [CrossRef]

72. Li, X.; Al-Yaari, A.; Schwank, M.; Fan, L.; Frappart, F.; Swenson, J.; Wigneron, J.P. Compared performances of SMOS-IC soil moisture and vegetation optical depth retrievals based on Tau-Omega and Two-Stream microwave emission models. Remote Sens. Environ. 2020, 236, 111502. [CrossRef]

73. Ulaby, F.T.; Allen, C.T.; Eger, G.; Kanemasu, E. Relating the microwave backscattering coefficient to leaf area index. Remote Sens. Environ. 1984, 14, 113-133. [CrossRef]

74. Shamambo, D.; Bonan, B.; Calvet, J.-C.; Albergel, C.; Hahn, S. Interpretation of ASCAT Radar Scatterometer Observations Over Land: A Case Study Over Southwestern France. Remote Sens. 2019, 11, 2842. [CrossRef]

75. Lievens, H.; Martens, B.; Verhoest, N.E.C.; Hahn, S.; Reichle, R.H.; Miralles, D.G. Assimilation of global radar backscatter and radiometer brightness temperature observations to improve soil moisture and land evaporation estimates. Remote Sens. Environ. 2017, 189, 194-210. [CrossRef]

76. Zribi, M.; Chahbi, A.; Shabou, M.; Lili-Chabaane, Z.; Duchemin, B.; Baghdadi, N.; Amri, R.; Chehbouni, A. Soil surface moisture estimation over a semi-arid region using ENVISAT ASAR radar data for soil evaporation evaluation. Hydrol. Earth Syst. Sci. 2011, 15, 345-358. [CrossRef]

77. Baghdadi, N.; Hajj, M.; El Zribi, M.; Bousbih, S. Calibration of the Water Cloud Model at C-Band for winter crop fields and grasslands. Remote Sens. 2017, 9, 969. [CrossRef]

78. Gherboudj, I.; Magagi, R.; Berg, A.A.; Toth, B. Soil moisture retrieval over agricultural fields from multi-polarized and multi-angular RADARSAT-2 SAR data. Remote Sens. Environ. 2011, 115, 33-43. [CrossRef]

79. Paris, J.F. The effect of leaf size on the microwave backscattering by corn. Remote Sens. Environ. 1986, 19, 81-95. [CrossRef]

80. Prévot, L.; Champion, I.; Guyot, G. Estimating surface soil moisture and leaf area index of a wheat canopy using a dual-frequency (C and X bands) scatterometer. Remote Sens. Environ. 1993, 46, 331-339. [CrossRef]

81. Kumar, K.; Hari Prasad, K.S.; Arora, M.K. Estimation des paramètres de végétation dans un modèle de nuage utilisant un algorithme génétique. Hydrol. Sci. J. 2012, 57, 776-789. [CrossRef]

82. Dabrowska-Zielinska, K.; Inoue, Y.; Kowalik, W.; Gruszczynska, M. Inferring the effect of plant and soil variables on C- and L-band SAR backscatter over agricultural fields, based on model analysis. Adv. Space Res. 2007, 39, 139-148. [CrossRef]

83. Du, J.; Kimball, J.S.; Jones, L.A.; Kim, Y.; Glassy, J.; Watts, J.D. A global satellite environmental data record derived from AMSR-E and AMSR2 microwave Earth observations. Earth Syst. Sci. Data 2017, 9, 791-808. [CrossRef]

84. Jones, L.A.; Kimball, J.S. Daily Global Land Surface Parameters Derived from AMSR-E, Version 1; Copernicus Publications: Göttingen, Germany, 2012.

85. Kim, Y.; Kimball, J.S.; Glassy, J.; Du, J. An extended global Earth system data record on daily landscape freeze-thaw status determined from satellite passive microwave remote sensing. Earth Syst. Sci. Data 2017, 9 , 133-147. [CrossRef] 
86. Du, J.; Kimball, J.S.; Jones, L.A. Passive Microwave Remote Sensing of Soil Moisture Based on Dynamic Vegetation Scattering Properties for AMSR-E. IEEE Trans. Geosci. Remote Sens. 2016, 54, 597-608. [CrossRef]

87. Mladenova, I.E.; Jackson, T.J.; Njoku, E.; Bindlish, R.; Chan, S.; Cosh, M.H.; Holmes, T.R.H.; de Jeu, R.A.M.; Jones, L.; Kimball, J.; et al. Remote monitoring of soil moisture using passive microwave-based techniques-Theoretical basis and overview of selected algorithms for AMSR-E. Remote Sens. Environ. 2014, 144, 197-213. [CrossRef]

88. LDPR v2. Available online: http://files.ntsg.umt.edu/data/LPDR_v2/ (accessed on 1 April 2020).

89. Liu, Y.Y.; De Jeu, R.A.M.M.; McCabe, M.F.; Evans, J.P.; Van Dijk, A.I.J.M. Global long-term passive microwave satellite-based retrievals of vegetation optical depth. Geophys. Res. Lett. 2011, 38. [CrossRef]

90. Owe, M.; de Jeu, R.; Holmes, T. Multisensor historical climatology of satellite-derived global land surface moisture. J. Geophys. Res. Earth Surf. 2008, 113, F01002. [CrossRef]

91. De Jeu, R.A.M.; Owe, M. Further validation of a new methodology for surface moisture and vegetation optical depth retrieval. Int. J. Remote Sens. 2003, 24, 4559-4578. [CrossRef]

92. Owe, M.; De Jeu, R.; Walker, J. A methodology for surface soil moisture and vegetation optical depth retrieval using the microwave polarization difference index. IEEE Trans. Geosci. Remote Sens. 2001, 39, 1643-1654. [CrossRef]

93. VUA-NASA Retrieval Products. Available online: https://www.geo.vu.nl/ \{\}jeur/lprm/ (accessed on 18 June 2020).

94. Moesinger, L.; Dorigo, W.; De Jeu, R.; Van Der Schalie, R.; Scanlon, T.; Teubner, I.; Forkel, M. The global long-term microwave Vegetation Optical Depth Climate Archive (VODCA). Earth Syst. Sci. Data 2020, 12, 177-196. [CrossRef]

95. De Nijs, A.H.A.; Parinussa, R.M.; De Jeu, R.A.M.; Schellekens, J.; Holmes, T.R.H. A Methodology to Determine Radio-Frequency Interference in AMSR2 Observations. IEEE Trans. Geosci. Remote Sens. 2015, 53, 5148-5159. [CrossRef]

96. Dorigo, W.; Wagner, W.; Albergel, C.; Albrecht, F.; Balsamo, G.; Brocca, L.; Chung, D.; Ertl, M.; Forkel, M.; Gruber, A.; et al. ESA CCI Soil Moisture for improved Earth system understanding: State-of-the art and future directions. Remote Sens. Environ. 2017, 203, 185-215. [CrossRef]

97. Holmes, T.R.H.; De Jeu, R.A.M.; Owe, M.; Dolman, A.J. Land surface temperature from Ka band (37 GHz) passive microwave observations. J. Geophys. Res. Atmos. 2009, 114. [CrossRef]

98. The Global Long-Term Microwave Vegetation Optical Depth Climate Archive VODCA. Available online: https://zenodo.org/record/2575599\#.XwwToefgpPY (accessed on 1 April 2020).

99. Fernandez-Moran, R.; Al-Yaari, A.; Mialon, A.; Mahmoodi, A.; Al Bitar, A.; De Lannoy, G.; Rodriguez-Fernandez, N.; Lopez-Baeza, E.; Kerr, Y.; Wigneron, J.P. SMOS-IC: An alternative SMOS soil moisture and vegetation optical depth product. Remote Sens. 2017, 9, 457. [CrossRef]

100. Wigneron, J.P.; Kerr, Y.; Waldteufel, P.; Saleh, K.; Escorihuela, M.J.; Richaume, P.; Ferrazzoli, P.; de Rosnay, P.; Gurney, R.; Calvet, J.C.; et al. L-band Microwave Emission of the Biosphere (L-MEB) Model: Description and calibration against experimental data sets over crop fields. Remote Sens. Environ. 2007, 107, 639-655. [CrossRef]

101. Wigneron, J.P.; Waldteufel, P.; Chanzy, A.; Calvet, J.C.; Kerr, Y. Two-dimensional microwave interferometer retrieval capabilities over land surfaces (SMOS Mission). Remote Sens. Environ. 2000, 73, 270-282. [CrossRef]

102. Products Access-Centre Aval de Traitement des Données SMOS (CATDS). Available online: https://www. catds.fr/Products/Products-access (accessed on 27 June 2020).

103. INRAE BORDEAUX Soil Moisture and VOD PRODUCTS—Soil Moisture and Vegetation Products. Available online: https://ib.remote-sensing.inrae.fr/ (accessed on 8 September 2020).

104. Kerr, Y.H.; Waldteufel, P.; Richaume, P.; Wigneron, J.P.; Ferrazzoli, P.; Mahmoodi, A.; Al Bitar, A.; Cabot, F.; Gruhier, C.; Juglea, S.E.; et al. The SMOS soil moisture retrieval algorithm. IEEE Trans. Geosci. Remote Sens. 2012, 50, 1384-1403. [CrossRef]

105. Al Bitar, A.; Mialon, A.; Kerr, Y.H.; Cabot, F.; Richaume, P.; Jacquette, E.; Quesney, A.; Mahmoodi, A.; Tarot, S.; Parrens, M.; et al. The global SMOS Level 3 daily soil moisture and brightness temperature maps. Earth Syst. Sci. Data 2017, 9, 293-315. [CrossRef]

106. Soldo, Y.; Khazaal, A.; Cabot, F.; Richaume, P.; Anterrieu, E.; Kerr, Y.H. Mitigation of RFIS for SMOS: A distributed approach. IEEE Trans. Geosci. Remote Sens. 2014, 52, 7470-7479. [CrossRef]

107. Khazâal, A.; Anterrieu, E.; Cabot, F.; Kerr, Y.H. Impact of Direct Solar Radiations Seen by the Back-Lobes Antenna Patterns of SMOS on the Retrieved Images. IEEE J. Sel. Top. Appl. Earth Obs. Remote Sens. 2017, 10, 3079-3086. [CrossRef] 
108. ESA SMOS Online Dissemination. Available online: https://smos-diss.eo.esa.int/oads/access/ (accessed on 27 June 2020).

109. Chan, S.K.; Bindlish, R.; O’Neill, P.E.; Njoku, E.; Jackson, T.; Colliander, A.; Chen, F.; Burgin, M.; Dunbar, S.; Piepmeier, J.; et al. Assessment of the SMAP Passive Soil Moisture Product. IEEE Trans. Geosci. Remote Sens. 2016, 54, 4994-5007. [CrossRef]

110. Chan, S.K.; Bindlish, R.; O’Neill, P.; Jackson, T.; Njoku, E.; Dunbar, S.; Chaubell, J.; Piepmeier, J.; Yueh, S.; Entekhabi, D.; et al. Development and assessment of the SMAP enhanced passive soil moisture product. Remote Sens. Environ. 2018, 204, 931-941. [CrossRef]

111. Piepmeier, J.R.; Johnson, J.T.; Mohammed, P.N.; Bradley, D.; Ruf, C.; Aksoy, M.; Garcia, R.; Hudson, D.; Miles, L.; Wong, M. Radio-frequency interference mitigation for the soil moisture active passive microwave radiometer. IEEE Trans. Geosci. Remote Sens. 2014, 52, 761-775. [CrossRef]

112. Njoku, E.G.; Li, L. Retrieval of land surface parameters using passive microwave measurements at 6-18 GHz. IEEE Trans. Geosci. Remote Sens. 1999, 37, 79-93. [CrossRef]

113. Chaubell, M.J.; Yueh, S.H.; Scott Dunbar, R.; Colliander, A.; Chen, F.; Chan, S.K.; Entekhabi, D.; Bindlish, R.; O'Neill, P.E.; Asanuma, J.; et al. Improved SMAP Dual-Channel Algorithm for the Retrieval of Soil Moisture. IEEE Trans. Geosci. Remote Sens. 2020, 58, 3894-3905. [CrossRef]

114. Lawrence, H.; Wigneron, J.P.; Demontoux, F.; Mialon, A.; Kerr, Y.H. Evaluating the semiempirical H-Q model used to calculate the l-band emissivity of a rough bare soil. IEEE Trans. Geosci. Remote Sens. 2013, 51, 4075-4084. [CrossRef]

115. Data Products|Data-SMAP. Available online: https://smap.jpl.nasa.gov/data/ (accessed on 30 June 2020).

116. Konings, A.G.; Piles, M.; Das, N.; Entekhabi, D. L-band vegetation optical depth and effective scattering albedo estimation from SMAP. Remote Sens. Environ. 2017, 198, 460-470. [CrossRef]

117. Konings, A.G.; Piles, M.; Rötzer, K.; McColl, K.A.; Chan, S.K.; Entekhabi, D. Vegetation optical depth and scattering albedo retrieval using time series of dual-polarized L-band radiometer observations. Remote Sens. Environ. 2016, 172, 178-189. [CrossRef]

118. MT-DCA. Available online: http://pangea.stanford.edu/konings/MT-DCA (accessed on 1 April 2020).

119. Vreugdenhil, M.; Dorigo, W.A.; Wagner, W.; De Jeu, R.A.M.; Hahn, S.; Van Marle, M.J.E. Analyzing the Vegetation Parameterization in the TU-Wien ASCAT Soil Moisture Retrieval. IEEE Trans. Geosci. Remote Sens. 2016, 54, 3513-3531. [CrossRef]

120. Vreugdenhil, M.; Hahn, S.; Melzer, T.; Bauer-Marschallinger, B.; Reimer, C.; Dorigo, W.A.; Wagner, W. Assessing Vegetation Dynamics Over Mainland Australia with Metop ASCAT. IEEE J. Sel. Top. Appl. Earth Obs. Remote Sens. 2017, 10, 2240-2248. [CrossRef]

121. Jackson, T.J.; Schmugge, T.J.; Wang, J.R. Passive microwave sensing of soil moisture under vegetation canopies. Water Resour. Res. 1982, 18, 1137-1142. [CrossRef]

122. Jackson, T.J.; Schmugge, T.J. Vegetation effects on the microwave emission of soils. Remote Sens. Environ. 1991, 36, 203-212. [CrossRef]

123. Kirdiashev, K.P.; Chukhlantsev, A.A.; Shutko, A.M. Microwave radiation of the earth's surface in the presence of vegetation cover. Radiotekhnika Elektron. 1979, 24, 256-264.

124. Schneebeli, M.; Wolf, S.; Kunert, N.; Eugster, W.; Mätzler, C. Relating the X-band opacity of a tropical tree canopy to sapflow, rain interception and dew formation. Remote Sens. Environ. 2011, 115, 2116-2125. [CrossRef]

125. Grant, J.P.; Wigneron, J.P.; Drusch, M.; Williams, M.; Law, B.E.; Novello, N.; Kerr, Y. Investigating temporal variations in vegetation water content derived from SMOS optical depth. In Proceedings of the International Geoscience and Remote Sensing Symposium (IGARSS), Munich, Germany, 22-27 July 2012; pp. 3331-3334.

126. Mätzler, C. Microwave transmissivity of a forest canopy: Experiments made with a beech. Remote Sens. Environ. 1994, 48, 172-180. [CrossRef]

127. Wigneron, J.P.; Pardé, M.; Waldteufel, P.; Chanzy, A.; Kerr, Y.; Schmidl, S.; Skou, N. Characterizing the Dependence of Vegetation Model Parameters on Crop Structure, Incidence Angle, and Polarization at L-Band. IEEE Trans. Geosci. Remote Sens. 2004, 42, 416-425. [CrossRef]

128. Schwank, M.; Mätzler, C.; Guglielmetti, M.; Flühler, H. L-band radiometer measurements of soil water under growing clover grass. IEEE Trans. Geosci. Remote Sens. 2005, 43, 2225-2236. [CrossRef]

129. Guglielmetti, M.; Schwank, M.; Mätzler, C.; Oberdörster, C.; Vanderborght, J.; Flühler, H. FOSMEX: Forest soil moisture experiments with microwave radiometry. IEEE Trans. Geosci. Remote Sens. 2008, 46, 727-735. [CrossRef] 
130. Pampaloni, P.; Paloscia, S. Microwave Emission and Plant Water Content: A Comparison between Field Measurements and Theory. IEEE Trans. Geosci. Remote Sens. 1986, GE-24, 900-905. [CrossRef]

131. Paloscia, S.; Pampaloni, P. Microwave vegetation indexes for detecting biomass and water conditions of agricultural crops. Remote Sens. Environ. 1992, 40, 15-26. [CrossRef]

132. Della Vecchia, A.; Ferrazzoli, P.; Guerriero, L.; Rahmoune, R.; Paloscia, S.; Pettinato, S.; Santi, E. Modeling the multifrequency emission of broadleaf forests and their components. IEEE Trans. Geosci. Remote Sens. 2010, 48, 270-272. [CrossRef]

133. Macelloni, G.; Paloscia, S.; Pampaloni, P.; Ruisi, R. Airborne multifrequency L- to Ka- band radiometric measurements over forests. IEEE Trans. Geosci. Remote Sens. 2001, 39, 2507-2513. [CrossRef]

134. Jones, M.O.; Jones, L.A.; Kimball, J.S.; McDonald, K.C. Satellite passive microwave remote sensing for monitoring global land surface phenology. Remote Sens. Environ. 2011, 115, 1102-1114. [CrossRef]

135. Chaparro, D.; Duveiller, G.; Piles, M.; Cescatti, A.; Vall-llossera, M.; Camps, A.; Entekhabi, D. Sensitivity of L-band vegetation optical depth to carbon stocks in tropical forests: A comparison to higher frequencies and optical indices. Remote Sens. Environ. 2019, 232, 111303. [CrossRef]

136. Van De Griend, A.A.; Owe, M. Determination of microwave vegetation optical depth and single scattering albedo from large scale soil moisture and nimbus/smmr satellite observations. Int. J. Remote Sens. 1993, 14, 1875-1886. [CrossRef]

137. Liu, Y.Y.; Van Dijk, A.I.J.M.; De Jeu, R.A.M.; Holmes, T.R.H. An analysis of spatiotemporal variations of soil and vegetation moisture from a 29 -year satellite-derived data set over mainland Australia. Water Resour. Res. 2009, 45. [CrossRef]

138. Friedl, M.A.; McIver, D.K.; Hodges, J.C.F.; Zhang, X.Y.; Muchoney, D.; Strahler, A.H.; Woodcock, C.E.; Gopal, S.; Schneider, A.; Cooper, A.; et al. Global land cover mapping from MODIS: Algorithms and early results. Remote Sens. Environ. 2002, 83, 287-302. [CrossRef]

139. Gao, B.-C. NDWI A Normalized Difference Water Index for Remote Sensing of Vegetation Liquid Water from Space. Remote Sens. Environ. 1996, 7212, 257-266. [CrossRef]

140. Grant, J.P.; Wigneron, J.P.; De Jeu, R.A.M.; Lawrence, H.; Mialon, A.; Richaume, P.; Al Bitar, A.; Drusch, M.; van Marle, M.J.E.; Kerr, Y. Comparison of SMOS and AMSR-E vegetation optical depth to four MODIS-based vegetation indices. Remote Sens. Environ. 2016, 172, 87-100. [CrossRef]

141. Lawrence, H.; Wigneron, J.P.; Richaume, P.; Novello, N.; Grant, J.; Mialon, A.; Al Bitar, A.; Merlin, O.; Guyon, D.; Leroux, D.; et al. Comparison between SMOS Vegetation Optical Depth products and MODIS vegetation indices over crop zones of the USA. Remote Sens. Environ. 2014, 140, 396-406. [CrossRef]

142. Hajj, M.; El Baghdadi, N.; Wigneron, J.P.; Zribi, M.; Albergel, C.; Calvet, J.C.; Fayad, I. First vegetation optical depth mapping from Sentinel-1 C-band SAR data over crop fields. Remote Sens. 2019, 11, 2769. [CrossRef]

143. Liu, Y.Y.; Van Dijk, A.I.J.M.; De Jeu, R.A.M.; Canadell, J.G.; McCabe, M.F.; Evans, J.P.; Wang, G. Recent reversal in loss of global terrestrial biomass. Nat. Clim. Chang. 2015, 5, 470-474. [CrossRef]

144. Rodríguez-Fernández, N.J.; Mialon, A.; Mermoz, S.; Bouvet, A.; Richaume, P.; Al Bitar, A.; Al-Yaari, A.; Brandt, M.; Kaminski, T.; Le Toan, T.; et al. An evaluation of SMOS L-band vegetation optical depth (L-VOD) data sets: High sensitivity of L-VOD to above-ground biomass in Africa. Biogeosciences 2018, 15, 4627-4645. [CrossRef]

145. Saatchi, S.S.; Harris, N.L.; Brown, S.; Lefsky, M.; Mitchard, E.T.A.; Salas, W.; Zutta, B.R.; Buermann, W.; Lewis, S.L.; Hagen, S.; et al. Benchmark map of forest carbon stocks in tropical regions across three continents. Proc. Natl. Acad. Sci. USA 2011, 108, 9899-9904. [CrossRef]

146. Baccini, A.; Goetz, S.J.; Walker, W.S.; Laporte, N.T.; Sun, M.; Sulla-Menashe, D.; Hackler, J.; Beck, P.S.A.; Dubayah, R.; Friedl, M.A.; et al. Estimated carbon dioxide emissions from tropical deforestation improved by carbon-density maps. Nat. Clim. Chang. 2012, 2, 182-185. [CrossRef]

147. Avitabile, V.; Herold, M.; Heuvelink, G.B.M.; Lewis, S.L.; Phillips, O.L.; Asner, G.P.; Armston, J.; Ashton, P.S.; Banin, L.; Bayol, N.; et al. An integrated pan-tropical biomass map using multiple reference datasets. Glob. Chang. Biol. 2016, 22, 1406-1420. [CrossRef] [PubMed]

148. Bouvet, A.; Mermoz, S.; Le Toan, T.; Villard, L.; Mathieu, R.; Naidoo, L.; Asner, G.P. An above-ground biomass map of African savannahs and woodlands at $25 \mathrm{~m}$ resolution derived from ALOS PALSAR. Remote Sens. Environ. 2018, 206, 156-173. [CrossRef] 
149. Tian, F.; Brandt, M.; Liu, Y.Y.; Verger, A.; Tagesson, T.; Diouf, A.A.; Rasmussen, K.; Mbow, C.; Wang, Y.; Fensholt, R. Remote sensing of vegetation dynamics in drylands: Evaluating vegetation optical depth (VOD) using AVHRR NDVI and in situ green biomass data over West African Sahel. Remote Sens. Environ. 2016, 177, 265-276. [CrossRef]

150. Brandt, M.; Wigneron, J.P.; Chave, J.; Tagesson, T.; Penuelas, J.; Ciais, P.; Rasmussen, K.; Tian, F.; Mbow, C.; Al-Yaari, A.; et al. Satellite passive microwaves reveal recent climate-induced carbon losses in African drylands. Nat. Ecol. Evol. 2018, 2, 827-835. [CrossRef] [PubMed]

151. Rahmoune, R.; Ferrazzoli, P.; Singh, Y.K.; Kerr, Y.H.; Richaume, P.; Al Bitar, A. SMOS retrieval results over forests: Comparisons with independent measurements. IEEE J. Sel. Top. Appl. Earth Obs. Remote Sens. 2014, 7, 3858-3866. [CrossRef]

152. Vittucci, C.; Ferrazzoli, P.; Kerr, Y.; Richaume, P.; Guerriero, L.; Rahmoune, R.; Laurin, G.V. SMOS retrieval over forests: Exploitation of optical depth and tests of soil moisture estimates. Remote Sens. Environ. 2016, 180, 115-127. [CrossRef]

153. Karthikeyan, L.; Pan, M.; Konings, A.G.; Piles, M.; Fernandez-Moran, R.; Nagesh Kumar, D.; Wood, E.F. Simultaneous retrieval of global scale Vegetation Optical Depth, surface roughness, and soil moisture using X-band AMSR-E observations. Remote Sens. Environ. 2019, 234, 111473. [CrossRef]

154. Momen, M.; Wood, J.D.; Novick, K.A.; Pangle, R.; Pockman, W.T.; McDowell, N.G.; Konings, A.G. Interacting Effects of Leaf Water Potential and Biomass on Vegetation Optical Depth. J. Geophys. Res. Biogeosci. 2017, 122, 3031-3046. [CrossRef]

155. Shi, J.; Jackson, T.; Tao, J.; Du, J.; Bindlish, R.; Lu, L.; Chen, K.S. Microwave vegetation indices for short vegetation covers from satellite passive microwave sensor AMSR-E. Remote Sens. Environ. 2008, 112, 4285-4300. [CrossRef]

156. Steele-Dunne, S.C.; Friesen, J.; Van De Giesen, N. Using diurnal variation in backscatter to detect vegetation water stress. IEEE Trans. Geosci. Remote Sens. 2012, 50, 2618-2629. [CrossRef]

157. Liu, Y.Y.; van Dijk, A.I.J.M.; McCabe, M.F.; Evans, J.P.; de Jeu, R.A.M. Global vegetation biomass change (1988-2008) and attribution to environmental and human drivers. Glob. Ecol. Biogeogr. 2013, 22, 692-705. [CrossRef]

158. Liu, Y.Y.; Evans, J.P.; McCabe, M.F.; de Jeu, R.A.M.; van Dijk, A.I.J.M.; Dolman, A.J.; Saizen, I. Changing Climate and Overgrazing Are Decimating Mongolian Steppes. PLoS ONE 2013, 8, e57599. [CrossRef] [PubMed]

159. Fan, L.; Wigneron, J.P.; Xiao, Q.; Al-Yaari, A.; Wen, J.; Martin-StPaul, N.; Dupuy, J.L.; Pimont, F.; Al Bitar, A.; Fernandez-Moran, R.; et al. Evaluation of microwave remote sensing for monitoring live fuel moisture content in the Mediterranean region. Remote Sens. Environ. 2018, 205, 210-223. [CrossRef]

160. Van Marle, M.J.E.E.; Van Der Werf, G.R.; De Jeu, R.A.M.M.; Liu, Y.Y. Annual South American forest loss estimates based on passive microwave remote sensing (1990-2010). Biogeosciences 2016, 13, 609-624. [CrossRef]

161. Del Frate, F.; Ferrazzoli, P.; Schiavon, G. Retrieving soil moisture and agricultural variables by microwave radiometry using neural networks. Remote Sens. Environ. 2003, 84, 174-183. [CrossRef]

162. Piles, M.; Camps-Valls, G.; Chaparro, D.; Entekhabi, D.; Konings, A.G.; Jagdhuber, T. Remote sensing of vegetation dynamics in agro-ecosystems using smap vegetation optical depth and optical vegetation indices. In Proceedings of the International Geoscience and Remote Sensing Symposium (IGARSS), Fort Worth, TX, USA, 23-28 July 2017; pp. 4346-4349.

163. Chaparro, D.; Piles, M.; Vall-llossera, M.; Camps, A.; Konings, A.G.; Entekhabi, D. L-band vegetation optical depth seasonal metrics for crop yield assessment. Remote Sens. Environ. 2018, 212, 249-259. [CrossRef]

164. Hornbuckle, B.K.; Patton, J.C.; VanLoocke, A.; Suyker, A.E.; Roby, M.C.; Walker, V.A.; Iyer, E.R.; Herzmann, D.E.; Endacott, E.A. SMOS optical thickness changes in response to the growth and development of crops, crop management, and weather. Remote Sens. Environ. 2016, 180, 320-333. [CrossRef]

165. Patton, J.; Hornbuckle, B. Initial validation of SMOS vegetation optical thickness in Iowa. IEEE Geosci. Remote Sens. Lett. 2013, 10, 647-651. [CrossRef]

166. Togliatti, K.; Hartman, T.; Walker, V.A.; Arkebauer, T.J.; Suyker, A.E.; VanLoocke, A.; Hornbuckle, B.K. Satellite L-band vegetation optical depth is directly proportional to crop water in the US Corn Belt. Remote Sens. Environ. 2019, 233. [CrossRef]

167. Van Emmerik, T.; Steele-Dunne, S.C.; Judge, J.; Van De Giesen, N. Impact of Diurnal Variation in Vegetation Water Content on Radar Backscatter from Maize During Water Stress. IEEE Trans. Geosci. Remote Sens. 2015, 53, 3855-3869. [CrossRef]

168. Fan, L.; Wigneron, J.-P.; Ciais, P.; Chave, J.; Brandt, M.; Fensholt, R.; Saatchi, S.S.; Bastos, A.; Al-Yaari, A.; Hufkens, K.; et al. Satellite-observed pantropical carbon dynamics. Nat. Plants 2019, 5, 944-951. [CrossRef] [PubMed] 
169. Wigneron, J.P.; Fan, L.; Ciais, P.; Bastos, A.; Brandt, M.; Chave, J.; Saatchi, S.; Baccini, A.; Fensholt, R. Tropical forests did not recover from the strong 2015-2016 El Niño event. Sci. Adv. 2020, 6, eaay4603. [CrossRef] [PubMed]

170. Teubner, I.E.; Forkel, M.; Jung, M.; Liu, Y.Y.; Miralles, D.G.; Parinussa, R.; van der Schalie, R.; Vreugdenhil, M.; Schwalm, C.R.; Tramontana, G.; et al. Assessing the relationship between microwave vegetation optical depth and gross primary production. Int. J. Appl. Earth Obs. Geoinf. 2018, 65, 79-91. [CrossRef]

171. Teubner, I.E.; Forkel, M.; Camps-Valls, G.; Jung, M.; Miralles, D.G.; Tramontana, G.; van der Schalie, R.; Vreugdenhil, M.; Mösinger, L.; Dorigo, W.A. A carbon sink-driven approach to estimate gross primary production from microwave satellite observations. Remote Sens. Environ. 2019, 229, 100-113. [CrossRef]

172. Eagleson, P.S. Climate, soil, and vegetation: 1 . Introduction to water balance dynamics. Water Resour. Res. 1978, 14, 705-712. [CrossRef]

173. Stephenson, N.L. Climatic control of vegetation distribution: The role of the water balance. Am. Nat. 1990, 135, 649-670. [CrossRef]

174. Neilson, R.P. A model for predicting continental-scale vegetation distribution and water balance. Ecol. Appl. 1995, 5, 362-385. [CrossRef]

175. Troch, P.A.; Martinez, G.F.; Pauwels, V.R.N.; Durcik, M.; Sivapalan, M.; Harman, C.; Brooks, P.D.; Gupta, H.; Huxman, T. Climate and vegetation water use efficiency at catchment scales Effects of Climate Variability on Water Balance Dynamics: Role of Vegetation. Process 2009, 23, 2409-2414.

176. Burke, E.J.; Gurney, R.J.; Simmonds, L.P.; O'Neill, P.E. Using a modeling approach to predict soil hydraulic properties from passive microwave measurements. IEEE Trans. Geosci. Remote Sens. 1998, 36, 454-462. [CrossRef]

177. Reichle, R.H.; Koster, R.D.; Dong, J.; Berg, A.A. Global soil moisture from satellite observations, land surface models, and ground data: Implications for data assimilation. J. Hydrometeorol. 2004, 5, 430-442. [CrossRef]

178. Schlenz, F.; Dall'Amico, J.T.; Mauser, W.; Loew, A. Analysis of SMOS brightness temperature and vegetation optical depth data with coupled land surface and radiative transfer models in Southern Germany. Hydrol. Earth Syst. Sci. 2012, 16, 3517-3533. [CrossRef]

179. Martens, B.; Miralles, D.G.; Lievens, H.; Van Der Schalie, R.; De Jeu, R.A.M.; Fernández-Prieto, D.; Beck, H.E.; Dorigo, W.A.; Verhoest, N.E.C. GLEAM v3: Satellite-based land evaporation and root-zone soil moisture. Geosci. Model Dev. 2017, 10, 1903-1925. [CrossRef]

180. Jones, M.O.; Kimball, J.S.; Jones, L.A.; McDonald, K.C. Satellite passive microwave detection of North America start of season. Remote Sens. Environ. 2012, 123, 324-333. [CrossRef]

181. Guan, K.; Wood, E.F.; Medvigy, D.; Kimball, J.; Pan, M.; Caylor, K.K.; Sheffield, J.; Xu, X.; Jones, M.O. Terrestrial hydrological controls on land surface phenology of African savannas and woodlands. J. Geophys. Res. G Biogeosci. 2014, 119, 1652-1669. [CrossRef]

182. Jones, M.O.; Kimball, J.S.; Jones, L.A. Satellite microwave detection of boreal forest recovery from the extreme 2004 wildfires in Alaska and Canada. Glob. Chang. Biol. 2013, 19, 3111-3122. [CrossRef] [PubMed]

183. Jones, M.O.; Kimball, J.S.; Nemani, R.R. Asynchronous Amazon forest canopy phenology indicates adaptation to both water and light availability. Environ. Res. Lett. 2014, 9, 124021. [CrossRef]

184. Tian, F.; Wigneron, J.-P.P.; Ciais, P.; Chave, J.; Ogée, J.; Peñuelas, J.; Ræbild, A.; Domec, J.-C.C.; Tong, X.; Brandt, M.; et al. Coupling of ecosystem-scale plant water storage and leaf phenology observed by satellite. Nat. Ecol. Evol. 2018, 2, 1428-1435. [CrossRef]

185. Konings, A.G.; Gentine, P. Global variations in ecosystem-scale isohydricity. Glob. Chang. Biol. 2017, 23, 891-905. [CrossRef]

186. Vittucci, C.; Vaglio Laurin, G.; Tramontana, G.; Ferrazzoli, P.; Guerriero, L.; Papale, D. Vegetation optical depth at L-band and above ground biomass in the tropical range: Evaluating their relationships at continental and regional scales. Int. J. Appl. Earth Obs. Geoinf. 2019, 77, 151-161. [CrossRef]

187. Li, X.; Wigneron, J.-P.; Frappart, F.; Fan, L.; Wang, M.; Liu, X.; Al-Yaari, A.; Moisy, C. Develoment and validation of the SMOS-IC version soil moisture product. In Proceedings of the IEEE IGARSS 2020, Waikoloa, HI, USA, 19-24 July 2020.

188. Prigent, C.; Papa, F.; Aires, F.; Rossow, W.B.; Matthews, E. Global inundation dynamics inferred from multiple satellite observations, 1993-2000. J. Geophys. Res. Atmos. 2007, 112. [CrossRef]

189. Prigent, C.; Papa, F.; Aires, F.; Jimenez, C.; Rossow, W.B.; Matthews, E. Changes in land surface water dynamics since the 1990s and relation to population pressure. Geophys. Res. Lett. 2012, 39. [CrossRef] 
190. Parrens, M.; Bitar, A.A.; Frappart, F.; Papa, F.; Calmant, S.; Crétaux, J.-F.; Wigneron, J.-P.; Kerr, Y. Mapping dynamic water fraction under the tropical rain forests of the Amazonian basin from SMOS brightness temperatures. Water 2017, 9, 350. [CrossRef]

191. Parrens, M.; Bitar, A.; Al Frappart, F.; Paiva, R.; Wongchuig, S.; Papa, F.; Yamasaki, D.; Kerr, Y. High resolution mapping of inundation area in the Amazon basin from a combination of L-band passive microwave, optical and radar datasets. Int. J. Appl. Earth Obs. Geoinf. 2019, 81, 58-71. [CrossRef]

192. Gao, L.; Sadeghi, M.; Ebtehaj, A. Microwave retrievals of soil moisture and vegetation optical depth with improved resolution using a combined constrained inversion algorithm: Application for SMAP satellite. Remote Sens. Environ. 2020, 239, 111662. [CrossRef]

193. Gevaert, A.I.; Parinussa, R.M.; Renzullo, L.J.; van Dijk, A.I.J.M.; de Jeu, R.A.M. Spatio-temporal evaluation of resolution enhancement for passive microwave soil moisture and vegetation optical depth. Int. J. Appl. Earth Obs. Geoinf. 2016, 45, 235-244. [CrossRef]

194. Ulaby, F.T.; El-Rayes, M.A. Microwave Dielectric Spectrum of Vegetation-Part II: Dual-Dispersion Model. IEEE Trans. Geosci. Remote Sens. 1987, GE-25, 550-557. [CrossRef]

195. Hauser, D.; Tison, C.; Amiot, T.; Delaye, L.; Corcoral, N.; Castillan, P. SWIM: The First Spaceborne Wave Scatterometer. IEEE Trans. Geosci. Remote Sens. 2017, 55, 3000-3014. [CrossRef]

196. Hauser, D.; Dong, X.; Aouf, L.; Tison, C.; Castillan, P. Overview of the CFOSAT mission. In Proceedings of the International Geoscience and Remote Sensing Symposium (IGARSS), Beijing, China, 10-15 July 2016; pp. 5789-5792.

197. Fatras, C.; Frappart, F.; Mougin, E.; Frison, P.L.; Faye, G.; Borderies, P.; Jarlan, L. Spaceborne altimetry and scatterometry backscattering signatures at $\mathrm{C}$ - and $\mathrm{Ku}$-bands over West Africa. Remote Sens. Environ. 2015, 159, 117-133. [CrossRef]

198. Frappart, F.; Fatras, C.; Mougin, E.; Marieu, V.; Diepkilé, A.T.; Blarel, F.; Borderies, P. Radar altimetry backscattering signatures at Ka, Ku, C, and S bands over West Africa. Phys. Chem. Earth 2015, 83-84, 96-110. [CrossRef]

199. Frappart, F.; Legrésy, B.; Niño, F.; Blarel, F.; Fuller, N.; Fleury, S.; Birol, F.; Calmant, S. An ERS-2 altimetry reprocessing compatible with ENVISAT for long-term land and ice sheets studies. Remote Sens. Environ. 2016, 184, 558-581. [CrossRef]

200. Frappart, F.; Blarel, F.; Papa, F.; Prigent, C.; Mougin, E.; Paillou, P.; Baup, F.; Zeiger, P.; Salameh, E.; Darrozes, J.; et al. Backscattering signatures at $\mathrm{ka}, \mathrm{ku}, \mathrm{c}$ and $\mathrm{s}$ bands from low resolution radar altimetry over land. Adv. Space Res. 2020. [CrossRef]

201. Fatras, C.; Frappart, F.; Mougin, E.; Grippa, M.; Hiernaux, P. Estimating surface soil moisture over Sahel using ENVISAT radar altimetry. Remote Sens. Environ. 2012, 123, 496-507. [CrossRef]

202. Bonnefond, P.; Verron, J.; Aublanc, J.; Babu, K.N.; Bergé-Nguyen, M.; Cancet, M.; Chaudhary, A.; Crétaux, J.-F.; Frappart, F.; Haines, B.; et al. The Benefits of the Ka-Band as Evidenced from the SARAL/AltiKa Altimetric Mission: Quality Assessment and Unique Characteristics of AltiKa Data. Remote Sens. 2018, 10, 83. [CrossRef]

203. Torres, R.; Snoeij, P.; Geudtner, D.; Bibby, D.; Davidson, M.; Attema, E.; Potin, P.; Rommen, B.Ö.; Floury, N.; Brown, M.; et al. GMES Sentinel-1 mission. Remote Sens. Environ. 2012, 120, 9-24. [CrossRef]

204. Jagdhuber, T.; Baur, M.; Akbar, R.; Das, N.N.; Link, M.; He, L.; Entekhabi, D. Estimation of active-passive microwave covariation using SMAP and Sentinel-1 data. Remote Sens. Environ. 2019, 225, 458-468. [CrossRef]

205. Motte, E.; Egido, A.; Roussel, N.; Boniface, K.; Frappart, F. Applications of GNSS-R in Continental Hydrology. In Land Surface Remote Sensing in Continental Hydrology; Elsevier: Amsterdam, The Netherlands, 2016; ISBN 9780081011812.

206. Zhang, S.; Roussel, N.; Boniface, K.; Cuong Ha, M.; Frappart, F.; Darrozes, J.; Baup, F.; Calvet, J.-C. Use of reflected GNSS SNR data to retrieve either soil moisture or vegetation height from a wheat crop. Hydrol. Earth Syst. Sci. 2017, 21, 4767-4784. [CrossRef]

207. Zhang, S.; Calvet, J.C.; Darrozes, J.; Roussel, N.; Frappart, F.; Bouhours, G. Deriving surface soil moisture from reflected GNSS signal observations from a grassland site in southwestern France. Hydrol. Earth Syst. Sci. 2018, 22, 1931-1946. [CrossRef]

208. Egido, A.; Paloscia, S.; Motte, E.; Guerriero, L.; Pierdicca, N.; Caparrini, M.; Santi, E.; Fontanelli, G.; Floury, N. Airborne GNSS-R polarimetric measurements for soil moisture and above-ground biomass estimation. IEEE J. Sel. Top. Appl. Earth Obs. Remote Sens. 2014, 7, 1522-1532. [CrossRef] 
209. Motte, E.; Zribi, M.; Fanise, P.; Baghdadi, N.; Baup, F.; Ben Hmida, S.; Dayau, S.; Fieuzal, R.; Guyon, D.; Wigneron, J.P. Results from the GLORIE GNSS-R airborne campaign: Agricultural areas. In Proceedings of the International Geoscience and Remote Sensing Symposium (IGARSS), Fort Worth, TX, USA, 23-28 July 2017; pp. 4106-4109.

210. Carreno-Luengo, H.; Luzi, G.; Crosetto, M. Biomass Estimation Over Tropical Rainforests Using GNSS-R On-Board the CyGNSS Microsatellites Constellation. In Proceedings of the IGARSS 2019-2019 IEEE International Geoscience and Remote Sensing Symposium, Yokohama, Japan, 28 July-2 August 2019; Institute of Electrical and Electronics Engineers (IEEE): Piscataway, NJ, USA, 2019; pp. 8676-8679.

(C) 2020 by the authors. Licensee MDPI, Basel, Switzerland. This article is an open access article distributed under the terms and conditions of the Creative Commons Attribution (CC BY) license (http://creativecommons.org/licenses/by/4.0/). 